Marquette University

e-Publications@Marquette

Economics Faculty Research and Publications

Economics, Department of

$12-1-2013$

\title{
The Impact of Interstate Highways on Land Use Conversion
}

Chris Mothorpe

Georgia State University

Andrew Hanson

Marquette University, andrew.r.hanson@marquette.edu

Kurt Schnier

Georgia State University

Accepted version. Annals of Regional Science, Vol. 51, No. 3 (December 2013): 833-870. DOI. (C) 2013 Springer. Used with permission.

Shareable Link. Provided by the Springer Nature SharedIt content-sharing initiative. 
The impact of interstate highways on land use conversion

Chris Mothorpe

Georgia State University

CMothorpe1@gsu.edu

Andrew Hanson

Marquette University

andrew.r.hanson@marquette.edu

Kurt Schnier

Georgia State University

KSchnier@gsu.edu

Between 1945 and 2007, the U.S. lost 19.3 percent of its agricultural land. Over the same time period, the construction of the 42,500 mile interstate highway system lowered transportation costs and opened large tracts of land for development. This paper assesses the impact of the interstate highway system on agricultural land loss in Georgia, and uses the empirical estimates to simulate agricultural land loss resulting from the construction of additional interstate highways. Using a historical dataset of agricultural land and interstate highway mileage, empirical estimates indicate that each additional mile of interstate highway reduces agricultural land by 468 acres. The impact of interstate highways is heterogeneous across initial level of county development. Urban counties convert seventy percent more land than the full sample estimates. Simulation results show that additions to the intestate system create further loss of agricultural land. The results imply that future conservation programs need to consider how to mitigate the impact of the interstate highway system.

Keywords: Land Conversion, Urban Sprawl

JEL Codes: R14, R11, R52, Q56 


\section{Introduction}

Between 1945 and 2007, the United States lost 19.23 percent of its agricultural land. ${ }^{1}$ Over the same time period, the construction of the interstate highway system led to a period of suburbanization (Baum-Snow 2007a) during which city boundaries and suburban areas expanded onto agricultural land. The loss of agricultural land directly reduces positive environmental benefits, including storm water management, recharging of water aquifers, open space preservation, and air purification (Lavingo et al. 2004). Agricultural land that is converted into residential suburban development, or urban sprawl, also carries negative externalities including urban core decay, air and water pollution, and inequality (Nechyba and Walsh 2004).

The primary mechanism through which interstate highways influenced development is reduced transportation costs brought about by design features of the system. ${ }^{2}$ As a result of lower transportation costs, land near interstate highways became more attractive to residents, business and manufacturing firms. There is a long established theoretical link between transportation costs and land conversion on the urban fringe (Alonso 1964; Mills 1967; Muth 1969); however, theoretical models and empirical work incorporating the interstate highway system into the urban form have only recently surfaced. Adding radial interstate highways to the Mills-Muth model raises the equilibrium utility level of the metropolitan area and alters the urban boundaries as the residential population shifts to take advantage of lower transportation costs (Baum-Snow 2007b). Empirical results confirm these predictions. Baum-Snow (2007a) shows that the

\footnotetext{
${ }^{1}$ We measure the loss of agricultural land as the percent change in acreage of agricultural land from 1945 to 2007.

${ }^{2}$ Interstate highways have a limited access design to promote faster commuting speeds.
} 
introduction of each additional radial interstate highway ray causes a nine percent decrease in central city population. Duranton and Turner (2012) investigate the impact of new interstate highway construction at the city level and find that a ten percent increase in the stock of interstate highways leads to a 1.5 percent increase in city population. In addition to influencing residential location decisions, the interstate highway system alters firms' location decisions by increasing the attractiveness of urban fringe land relative to city land. First, it reduces firms' dependence on rail and water transportation systems thereby enabling firms to move away from city centers. Second, it enables firms to more easily access markets located in other cities, which potentially increases firms' profitability when they locate on routes between cities. Empirical studies reveal that the construction of interstate highways in rural counties increases economic activity in counties they pass through, (Michaels 2008; Chandra and Thompson 2000) but they draw economic activity away from nearby counties that do not contain an interstate highway (Chandra and Thompson 2000).

While previous research establishes suggestive links between agricultural land loss and interstate construction, the purpose of this paper is to study the impact of interstate highways on the conversion of land from agricultural to other uses. Understanding the relationship between interstate expansion and agricultural land conversion is important to assist policymakers in designing agricultural land preservation policies as well as evaluating the impact of future interstate construction on the urban form. We focus on agricultural land since it is generally flat to gently sloping, well drained and cleared, not prone to erosion (Lavingo et al. 2004), and already connected to existing transportation infrastructure. These features make it the lowest cost and easiest to develop; therefore, agricultural land loss is a good proxy for newly urbanized land. Our 
research contributes to the literature in two ways. First, we use historical data on interstate highway construction to estimate the effects of interstate highway on land conversion. The majority of interstate highway construction occurred over a time period from 1959 to 1982 , and we capture observations at several points within this time frame. The variation in opened interstate highway miles over time allows us to capture gradual changes in non-agricultural land before, during and after the major period of interstate construction. Second, we use estimates from the model to simulate the impact of future interstate construction. These simulations allow us to predict "what if" scenarios describing land use change for proposed interstate highways that are not built and widening the existing footprint of the interstate highway system.

We use data from the state of Georgia, because it experienced large losses of agricultural land (57.1 percent) while at the same time experienced robust growth in population (7.6 percent annually) and interstate highway mileage $(1,240$ miles constructed) during this time period. We use historical county level data to model land use transitions dating back to the 1940s in order to provide a sufficient time horizon to identify key factors. Determining a causal relationship between interstate highways and land use conversion is difficult, as it is possible that owners of converted land demand highways to facilitate transportation versus interstate highways driving the demand for land conversion. To account for the potential endogenous relationship between interstate highways and land use conversion, we follow a similar strategy to that employed by Baum-Snow (2007a), and use the map of the 1947 national system for interstate highways (1947 NSIH) to construct two instrumental variables. We extend the analysis by examining the potential for interstate construction to have heterogeneous effects across different initial levels of county development. Finally, we simulate the 
amount of land conversion in response to a 200 mile circumferential interstate route surrounding Atlanta (the Outer Perimeter), a new interstate connecting I-85 to I-75 north of Atlanta (the Northern Arc), a new interstate highway connecting Augusta, GA to Natchez, MS (the Fourteenth Amendment highway), and the impact of building the current foot print of the interstate system with twice or half as many miles.

We find that each additional mile of interstate highway corresponds to 468 acres of agricultural land conversion. Additionally, our results indicate that the impact of interstate highway construction is largest in urban counties.

Constructing the Outer Perimeter in the Atlanta area would lead to between a 3.74 and 6.8 percent loss in agricultural land, connecting interstates 85 and 75 north of Atlanta would cause a 3.2 percent loss in agricultural land and the proposed new highway between Augusta, GA and Natchez, MS would result in a 22.65 percent loss of agricultural land. ${ }^{3}$ Our simulations also predict that doubling interstate highway miles in Georgia causes a loss of 2.6 million acres of agricultural land.

The remainder of the paper begins with a brief background on the interstate highway system and land use trends in Georgia. Section 3 is a discussion of the methodology we employ to model land conversion. Section 4 describes our data sources and provides summary statistics. Section 5 discusses our results and key findings while Section 6 presents simulations. Section 7 concludes.

\footnotetext{
${ }^{3}$ We calculate the percent loss of agricultural land in only those counties receiving a new interstate.
} 


\section{Background}

\subsection{Interstate Highway System History}

The foundation for the Eisenhower interstate highway system began with a series of Federal Aid Highway Acts in the 1930s and 1940s that called for a national system of 40,000 interstate highway miles to connect major population and economic centers. Selection of the first 37,700 miles of routes occurred in the 1940s, but the Federal government committed limited funds, which hampered early construction projects (U.S. Department of Transportation 2011). It was not until the passing of the Federal Aid Highway Act of 1956 that the Federal government created a mechanism that generated a sufficiently large revenue stream to fund interstate highway construction.

Title II of the Federal Aid Highway Act of 1956 created the Highway Trust Fund to pay the Federal share while Title I added route mileage, established nationwide design standards and set the federal share of project costs at ninety percent. ${ }^{4}$ The intent of the nationwide standards was to keep traffic moving at fifty to seventy miles per hour and included at least two lanes in each direction, limited access control, and no at grade intersections (AASHTO 2005). These standards eliminated any systematic hindrances to high-speed traffic flow such as traffic lights and were essential in lowering transportation costs. Subsequent Federal Highway Aid Acts marginally increased the system mileage and the final length of the system as of 1998 is 45,012 miles (U.S. Department of Transportation 2011).

Figure 1 shows Georgia's interstate highways and designates each route according to its inclusion in the $1947 \mathrm{NSIH}$, inclusion in the interstate system by

\footnotetext{
${ }^{4}$ Gas and other motor vehicle taxes provided a revenue stream for the Highway Trust Fund. The state share of project costs is the remaining ten percent.
} 
1956 or inclusion in the system after 1956. The 1947 NSIH included seven routes through Georgia, and each route is designed to serve as a connection between one or more metropolitan areas. Federal legislation expanded the interstate routes in Georgia by adding I-285 and I-475 in 1956 to serve as bypasses around Atlanta and Macon respectively and by adding the I-185 spur to connect the I-85 to Columbus in 1968. Together, these ten routes comprise Georgia's portion of the original interstate highway system. ${ }^{5}$

The first five miles of interstate routes opened in 1953, (U.S. Department of Transportation 1993) and by 1979 of all routes in the original system were complete (Georgia Department of Transportation 1981). Since 1980, eight expansion projects spanning thirty-two counties extended the system beyond the original plan (U.S. Department of Transportation 1980-2008). Major additions to the interstate system include spurs or bypasses, such as I-575 or I-516, and lane widening projects. The largest lane expansion project, dubbed "Freeing the Freeways", reconstructed 122 miles of interstates highways in the Atlanta metro area (Georgia Department of Transportation 1989) and increased the lane-miles from 500 in 1980 to 1,400 in 1990.

Figure 2 contains seven maps representing opened miles of interstates highways for years in the sample between 1959 and $1987 .^{6}$ In 1959 , there are a few miles of opened interstates located in the Atlanta metro area. The 1960s and 1970s saw the majority of interstate construction occur as the system expanded throughout the state. Since the majority of interstates opened after 1959 and before 1982, we refer to the intervening years as the highway building period.

\footnotetext{
${ }^{5} \mathrm{I}-185$ is considered to be in the original interstate highway system even though it did not open until after 1979,

${ }^{6}$ The first segment of I-75 opened prior to 1954 and the last segment of I-675 opened after 1987; however their small relative lengths make them indistinguishable on a map containing all interstates.
} 
After 1982, small additions such as spurs and bypasses opened, and the cumulative interstate mileage in Georgia approached 1,240 miles. There has been no new interstate route construction in Georgia since 1992.

\subsection{Land Use Trends}

Agricultural land is subject to many different forces that act concurrently to influence conversion of agricultural land to urban purposes. For example, Georgia experienced robust population growth that averaged 7.64 percent per year between 1945 and 2007 and 1,240 miles of interstate opened during this same time period. Trends in agricultural land, population and opened interstate highway miles (in feet) in the sample period are shown in Figure 3. The shaded region represents the highway building period.

The amount of non-agricultural land in Georgia fell between 1945 and 1950, but then began a long steady rise until 1992. For years after 1992, the amount of non-agricultural land leveled off and remained fairly constant through 2007. The population grew at a steady rate over the entire time period, but experienced faster growth for the years after 1987. Both the population and nonagricultural land trends increased from 1950 to 1992, suggesting that an increase in population leads to more agricultural land conversion. The two trends diverged after 1992 as the population continued to increase while the amount of nonagricultural land leveled off.

The influence of interstate highways on land conversion is unclear from the figure as the trend in non-agricultural land increased prior to the highway building period; however, it appears that interstate highways may have accelerated the rate of change. The conversion of agricultural land to urban uses began to increase in 1954 which is around the time the first interstate segment opened; 
however, it is unlikely that this small segment influenced a statewide trend. Throughout the highway building period, there is a constant upward trend in acreage of non-agricultural land suggesting that there may be a relationship between land conversion and interstate highway construction.

The growth in opened interstate highways miles, population and nonagricultural land coincided with a transition of a large number of counties into Metropolitan Statistical Areas (MSA). In 1950, Georgia contained all or portions of six MSAs covering ten counties that encompassed 2.2 million acres of land (six percent of the total area). By 2007, the state contained all or portions of fifteen MSAs covering seventy-two counties that encompassed 15.6 million acres (fortytwo percent of all land).

Panels A and B of Figure 4 display Georgia's urban (white), transitory (cross-hatched) and rural (gray) counties. We define counties as urban if they are always in an MSA in our sample period(white), transitory if they transitioned into an MSA by the end of 2007 (cross-hatched) and rural if they remained outside an MSA for the entire sample period (gray). Panel A overlays the state with the interstate highway system in 2007 and the cumulative interstate highway miles while Panel B contains population growth. Urban and transitory counties experienced faster population growth rates while rural counties experienced almost no population growth. The average population growth for transitory counties is 3.35 percent, for urban counties is 4.01 percent and for rural counties is 0.043 percent. The large population growth in urban counties is largely fueled by Cobb and Richmond counties, which are outliers in the distribution. Panel A of the figure also shows that the intersections of all of Georgia's main interstate highway routes occur in urban counties, which is not surprising since the interstate system is designed to connect major cities together. All bypasses are 
located in urban counties and spur routes (except I-185) are located in transition counties. The construction of each spur or bypass occurred after its county(ies) of location transitioned into an MSA. ${ }^{7}$ The location of spurs and bypasses as well as their opening dates suggest that the purpose of their construction was to alter existing traffic patterns or meet local commuting demands.

\section{Methodology}

Examining the long-term trends in Georgia demonstrates that multiple factors may be influencing agricultural land conversion; therefore, it is necessary to conduct multivariate analysis to net out differential impacts of the various economic factors. We use both ordinary least squares and instrumental variable estimation to relate the change in non-agricultural land to the economic variables of interest. The analysis focuses on the historical influence of all variables and includes three specifications to correct for potential endogeneity bias when estimating the causal relationship between highway building and agricultural land conversion. These specifications rely on the 1947 NSIH plan as a source of exogenous variation. The first strategy uses OLS and replaces opened interstate highway miles with opened interstate highway miles included in the $1947 \mathrm{NSIH}$, which eliminates spur and bypass routes. The other strategies use instrumental variable regression and different instruments constructed from the $1947 \mathrm{NSIH}$ plan.

The main specification for the ordinary least squares estimation is:

non agriclutural land $_{i t}=\alpha+\beta_{1}$ highway miles $_{i t}+\beta_{2}$ rain fall $_{i t}+$

$\beta_{3}$ population $_{i t}+\beta_{4}$ government land $_{i t}+\beta_{5}$ revenue $_{i t}++\gamma C_{i}+\delta Y_{t}+\varepsilon_{i t}$

\footnotetext{
${ }^{7}$ To determine if a route opened before or after a county transitioned into a MSA, we compare the date on which the last segment of the route opened to the traffic to the first year the county is included in a MSA by the U.S. Census Bureau.
} 
Subscript $i$ and $t$ represent counties and years respectively. We use the acreage of non-agricultural land as the dependent variable as it serves as a proxy for the amount of urbanized land area in the county. The variable of interest is highway miles, and it is the mileage of opened interstates highways in county $i$ in year $t$. Our control variables are inches of rain fall in the previous year (rain fall), population (population), acreage of government owned land (government land) and total revenue, in 2007 dollars, from the sale of corn, wheat, peanuts, and soybeans minus the transportation costs necessary to ship the produce to the nearest transportation center (revenue). Since our data is a non-random sample across fourteen years, it is highly likely that the residuals are correlated across years. To account for this, we use clustered standard errors at the county level. We report estimates for four variations of equation (1): 1) no year or county fixed effects, 2) year fixed effects $\left.\left(Y_{t}\right), 3\right)$ county fixed effects $\left(C_{i}\right)$, and 4) year and county fixed effects. We include year and county dummy variables to control for year or county specific effects that may or may not be observable. For example, year dummy variables capture technological improvements since technology varies by year but is constant across all counties as every farmer has equal access to technology. Likewise, county fixed effects control for county specific factors that are constant over time. These effects are important since some counties may hold a relative advantage in agricultural production due to land characteristics (e.g., soil quality).

To account for the potential endogeneity problem between opened interstate highway miles and acres of non-agricultural land that arises since some interstate highways may have been built to facilitate local commuting patterns, we implement two strategies. The first strategy we use to correct for endogeneity bias uses OLS and replaces opened interstate highway miles (highway miles) with 
opened miles of interstate highways in the $1947 \mathrm{NSIH}$ plan (NSIH Miles). The resulting specification is:

$$
\begin{aligned}
& \text { non agriclutural land }_{i t}=\alpha+\beta_{1} \text { NSIH miles }_{i t}+\beta_{2} \text { rain fall }_{i t}+ \\
& \beta_{3} \text { population }_{i t}+\beta_{4} \text { government land }_{i t}+\beta_{5} \text { revenue }_{i t}+\gamma C_{i}+\delta Y_{t}+\varepsilon_{i t}
\end{aligned}
$$

In equation (2), NSIH Miles represents the mileage of interstate highways in 1947 NSIH plan that are opened for use at the beginning of year $t$ for county $i$. We define all other variables and indices as in equation (1).

Our second strategy is to use an instrumental variable approach similar to that employed by Baum-Snow (2007b). Following Baum-Snow (2007b) we use the 1947 NSIH plan to construct instrumental variables to correct for the endogeneity problem. The first instrumental variable specification uses the opened interstate highway miles in the 1947 NSIH plan (NSIH Miles) as an instrument for opened interstate highway miles (Highway Miles), and the second instrumental specification uses changes in opened interstate highway miles in the 1947 NSIH (Chg NSIH Miles) as an instrument for changes in opened interstate highway miles. ${ }^{8}$ The validity of these instruments depends on the correlations between interstate highway miles in the 1947 NSIH plan, opened interstate highway miles and acreage of non-agricultural land. Additionally, the key underlying assumption we make by using the $1947 \mathrm{NSIH}$ plan as an instrument is that the specific alignments of interstate highway routes are exogenous. To meet these conditions, the 1947 NSIH plan interstate highway miles need to be correlated with actual interstate miles opened and uncorrelated with changes in

\footnotetext{
${ }^{8}$ One potential concern with our choice of instruments is that changes in non-agricultural land influenced the timing of interstate highway construction or the timing of when interstate highway segments opened for use. We estimate the model using cumulative miles the 1947 NSIH miles interacted with year dummies as an instrument, and our results did not change significantly, these results are available upon request.
} 
acreage of non-agricultural land except through their correlation with actual interstate highway building.

The motivation for the original highway plan seems to suggest that the instrument easily passes the exclusion restriction, as routes in the $1947 \mathrm{NSIH}$ are designed to "...connect by routes, direct as practical, the principal metropolitan areas, cities, and industrial centers, to serve the National Defense, and to connect at suitable border points, routes of continental importance in the Dominion of Canada and the Republic of Mexico" (U.S. Department of Transportation 2011). Routes are uncorrelated with either urbanized or agricultural land since they are designed to connect cities in the most direct way, did not change to accommodate developed or undeveloped land, and were not selected in anticipation of future population growth. In addition, the 1947 plan does not include beltways or bypasses meant to divert traffic or any later additions to the system such as I-575 and I-985 (see Figure 1). These two facts imply that local commuting patterns or acreage of non-agricultural land are not a factor in determining the location of interstate highway routes.

There are three remaining concerns with using the 1947 NSIH plan to construct instrumental variables. First, local municipal governments may have chosen to develop sections of the planned interstate system before federal funding became available or may have developed other high capacity roads that could be readily converted into interstates at lower costs relative to new highway construction. These previously built high-capacity roads could alter the route of the 1947 NSIH plan. Furthermore, residential voting patterns influence local governments; therefore the selection of these routes is not exogenous as residents can exert pressure on decision makers to select routes based on local commuting patterns (Baum-Snow 2007a). Second, areas with higher initial level of 
population or non-agricultural land may have received more interstate miles since the original plan was to connect major economic and population centers together. Finally, there may be endogeneity between interstate highway construction and development of agricultural land. If interstate highway construction occurred in developing areas first before their rural counterparts, the instrument is not exogenous.

In regards to the first concern, we note that portions of the 1947 NSIH built before federal funds became available are small relative to the whole system. In regards to the second concern, the inclusion of county level fixed effects ensures that the initial level of county development does not influence future changes in non-agricultural land attributable to the construction of the interstate highway system. For the third concern, we construct another instrument using the NSIH planned highways. This instrument multiplies the 1947 NSIH plan miles by the ratio of open $1947 \mathrm{NSIH}$ miles within the state to the total number of statewide 1947 NSIH miles. All counties containing 1947 NSIH plan miles receive some open mileage; therefore the instrument removes endogeneity that may arise from 1947 plan miles opening first in areas where demand for conversion of agricultural land is high.

\subsection{Robustness Checks}

We conduct a robustness check on our estimates by limiting the control group of counties to those counties that border counties receiving interstate highways. Figure 5 contains a map of Georgia's counties and their classification into three categories: 1) contain interstate highway mileages, 2) borders at least one county with interstate mileage and 3) does not border a county with interstate mileage. Sixty-five of Georgia's counties are within category 1, sixty are in category 2 and the remaining thirty-four are in category 3. Our main concern is 
that a control group containing all counties in Georgia not receiving interstate highway miles (categories $2 \& 3$ ) will contain some counties that do not contain similar unobservables to the treatment group. By limiting the control group to those counties in category 2 , our estimates tease out the difference between counties receiving interstate mileage and those counties that are most similar in nature to those in category 1 , but did not receive any interstate mileage.

\subsection{Heterogeneous Impact of Interstates Highways on Land Use Conversion}

As an extension to the primary model, we estimate the coefficients for equation (1) by county type to investigate heterogeneous impacts since the initial level of development may influence the marginal effects of variables.

Heterogeneous impacts may arise due the fact that urban interstates opened first and through the effect of land prices on land consumption. ${ }^{9}$ The construction of interstate highways provided residents and firms with increased access to large tracts of land on the urban periphery. As people and firms spread out along highways, land closest to the central city is developed followed by tracts farther away. This pattern of development allowed people and firms to enjoy locations with lower land prices while minimizing transportation and commuting costs. The cumulative effect of the process implies that interstates highway have the largest impact in urban counties since urban counties experienced the influence of interstate highways the longest.

Land prices affect the quantity of land that firms and people use and where they locate. The classic monocentric city model demonstrates that improvements in transportation technology or infrastructure lower commuting speeds in the urban area. Lower commuting speeds induces a price effect on residents since

\footnotetext{
${ }^{9}$ Panels for year 1959, and 1964 in Figure 2 show that there is a concentration of interstate construction in these years is located in the Atlanta MSA.
} 
individuals can consume more land given their fixed income, and it also induces a wealth effect since residents have increased amounts of disposable income. Manufacturing firms may locate in transitory or rural counties to take advantage of large tracts of undeveloped land that does not require substantial costs to develop or redevelop relative to developed land in urban counties. This, in turn, attracts employees to live nearby and leads to the development of a service sector to meet their needs. Constructing an interstate through a county causes the development of land; however, differences in land prices across county types influence cumulative quantity of land consumed and the overall effect of additional interstate mileage.

To estimate the impacts for urban, rural and transitory counties, we use the specification in equation (1) and restrict the estimation by county type. In each of the estimations, we include the full set of control variable including year and county fixed effects.

\section{Data}

We use a panel data set containing information on Georgia's 159 counties covering years from 1945 to 2007 . Data is captured at roughly five year intervals corresponding with the years the U.S. Census of Agriculture is conducted, and thus provides us with fourteen distinct time periods. ${ }^{10}$ An observation in our data set is a county-year, and it contains 2,226 observations. Since our data covers a relatively long time period we account for inflation by using the consumer price index to adjust all dollar amounts to 2007 dollars.

\footnotetext{
${ }^{10}$ There are fourteen years in the time period: $1945,1950,1954,1959,1964,1969,1974,1978$, 1982, 1987, 1992, 1997, 2002, and 2007.
} 


\subsection{Interstate Highway Miles}

The U.S. Department of Transportation provided data for interstate highway miles through two datasets. The first is the Status of Improvement of the National System of Interstate and Defense Highways File PR-511, which tracks the development of the Interstate Highway System from the early 1950s until 1993. Interstates are divided by route number and then into smaller segments. For each segment, the beginning mile post, length, and opening date are recorded. The last update of the PR-511 file occurred on June 30, 1993 and does not cover all years in the sample; therefore, we used information from the Federal Highway Administration's (FHWA) Highway Performance Monitoring System (HPMS) to account for interstate highway construction between 1993 and 2007. The FHWA maintains the HPMS dataset to "reflect the extent, condition, performance, use, and operating characteristics of the nation's highways" (U.S. Department of Transportation 2010), and it is updated annually. Similar to the PR-511 file, the HPMS dataset breaks down interstates into sub county segments and records route number and segment length for each segment. By aggregating segment length by county and route number and comparing across years, we are able to determine any new additions to the system.

To derive a geographic representation of Georgia's interstate highway system, we combine the PR-511 and HPMS datasets with the National Highway Planning Network (NHPN). The NHPN is a geographic representation of all of the nation's principal arterial roads. We use the beginning mile post and segment length from the PR-511 data set to spatially match interstate segments onto the NHPN. We then intersect the PR-511 end points with the NPHN segments to create a geographic dataset of interstates that is split by the PR-511 segments. The geographic dataset allows us to work backwards to construct interstate 
highway maps in Georgia (see Figure 2) and calculate open interstate miles (highway miles) per county for each year in the sample.

To calculate the total mileage of interstates included in the 1947 NSIH at the county level, we use a map of the 1947 NSIH and create an indicator for included interstates. ${ }^{11}$ We interact the indicator for inclusion with segment length in 2007 and aggregate to the county level. This aggregate interaction term is the county level miles of interstate highways in the 1947 NSIH and does not vary overtime. We use information in the PR-511 and HPMS data set to calculate opened miles in the 1947 NSIH per year (NSIH Miles). The procedure follows the steps described above, but we only use open interstate segments for that particular year. This variable varies over time since interstate highway construction unfolds over several years in the sample. Using this new variable, we construct the changes in opened miles in the 1947 NSIH (Chg NSIH Miles) by taking the difference between observations across sample years at the county level.

\subsection{U.S. Census of Agriculture}

The purpose of the U.S. Census of Agriculture is to provide a detailed picture of U.S. agricultural operations. For each county, the acreage of all farm land and quantity of crops produced is reported. Land that is reported by farmers as fallow and not used for agricultural purposes is deleted during data processing operations. If a farm straddled the boundary between two or more counties, then the farm's data are credited to the operator's principal county. The operator's principal county is defined as the one where the largest value of agricultural products are raised or produced. We extracted county level data information on the acreage of land by type and farm production quantities for all years in the time

\footnotetext{
${ }^{11}$ See Baum-Snow (2007a) for the full map of the 1947 plan the National System of Interstate Highways.
} 
period. We defined non-agricultural land as total acreage of a county minus the acreage of farm land. ${ }^{12}$

For each county, the acreage of all land, farm land, crop land, wood land and all other land is reported. Crop land is further subdivided into specific crops harvested, pasture land and all other crop land. The hierarchical structure of reported acreage is shown in Figure 6.

\subsection{Price Data}

We create a new variable, average revenue net transportation costs (revenue), to capture the effect of crop prices on land use change. Since crop quantity is endogenous to the amount of non-agricultural land, revenue is a laspeyres index that uses corn, wheat, soybean, and peanut quantities from 1950 as the basket of goods. We use data from the year 1950 instead of 1945 since World War II may have skewed agricultural production. All farmers face the same market price; however, the amount a farmer receives depends on transportation costs to ship produce to the market place. Therefore, we subtract transportation costs from revenue received from crops sales to derive the amount farmers received. Average revenue net transportation costs is calculated according to the following formula:

$$
\text { revenue }_{i t}=\sum_{j}\left(p_{j t} q_{i j 1950}-{\text { dis } \tan c e_{i}}^{*}{\text { mile } \left.\cos t_{t} * \text { trips }_{i 1950}\right)}\right)
$$

In equation (5), $i, t$, and $j$ represents a counties, years, and crops (wheat, soybeans, peanuts, and corn) respectively. Distance is the mileage from the centroid of a county to the nearest port or major shipping center (Atlanta, Macon, Brunswick, or Savannah). Mile cost is the per mile cost of gasoline for a semi-truck. Trips is

\footnotetext{
${ }^{12}$ Non-agricultural land is negative in three cases due to data calculation procedures.
} 
the number of trips it would take to ship all agricultural produce to the nearest port or major shipping center. ${ }^{13} P$ is the price of a crop and $q$ is the crop quantity.

We gather data on crop prices from the USDA's Crop Production Historical Track Records April 2011 report (U.S. Department of Agriculture 2011). Crop quantity information is from the Census of Agriculture, and we use four crops type: corn, wheat, soybeans and peanuts. Table 1 contains a breakdown of crop value relative to the total of market value of all crops sold. Historically, these four crops represent approximately fifty percent of agricultural product sold from the state of Georgia.

We obtain information regarding the fuel efficiency of tractor trailer trucks from the Transportation Energy Data Book (Davis et al. 2011). It contains speed dependent fuel economy information for semi-trucks depending on the speed unadjusted for terrain. We take the average miles per gallon (mpg) for single and dual tire tractor trailers at speeds of fifty-five miles per hour, which is $6.7 \mathrm{mpg}$. To calculate the one mile driving costs of a semi-truck, we invert the average miles per gallon for tractor trailer and multiply it by the average cost of gasoline that year. Prices before 2005 are from the U.S. Department of Energy's vehicle technology program and 2007 prices are from the U.S. Energy Information System. ${ }^{14,15}$ We use the price of gasoline since diesel prices are unavailable before 1970.

To compute the number of trips it takes farmers to ship the agricultural produce to the market, we calculate the total weight of corn, soybeans, peanuts,

\footnotetext{
${ }^{13}$ We use constant technology standards (as of 2007) for fuel efficiency and truck capacity. This biases our estimates downwards since fuel efficiency has improved and truck capacity has increased over time. Before 1956, there was no limit on truck loads, from 1956 to 1975 the limit was 73,280 pounds, and the current limit is 80,000 pounds. Fuel efficiency rates for 1970 through 2007 can be found in the Transportation Energy Data Book.

${ }^{14}$ Available from http://www1.eere.energy.gov/vehiclesandfuels/facts/2005/fcvt_fotw364.html

${ }^{15}$ Available from http://www.eia.gov/petroleum/data.cfm\#prices
} 
and wheat grown and divided it by the load capacity of a semi-truck. The maximum allowable gross weight of a semi-truck on an interstate is 80,000 pounds (U.S. Department of Transportation 1995). We assume that all trucks weigh in at the high end of the range and therefore, the total weight capacity of produce is 54,000 pounds. To calculate the total weight of agricultural product produce, we use commercial bushel sizes and multiply these amounts by the quantity of bushels. ${ }^{16}$ The formula for calculating the number of trips is as follows:

$$
\text { Trips }_{i 1950}=\frac{\text { peanut }_{i 1950}+70 * \operatorname{corn}_{i 1950}+60 *\left(\text { wheat }_{i 1950}+\text { soybeans }_{i 1950}\right)}{54,000}
$$

\subsection{Other Data Sources}

We collect rain fall data from the National Climatic Data Center's Surface Data Monthly summary for every station in Georgia as well as every station in a county bordering the state. We attribute station data to counties based on county of residence. If a county contains one or more weather stations, then the rain fall variable is set to the average of the stations' data. If a county does not contain a weather station, then its rainfall variables are set to the average of the bordering counties which contain a weather station. ${ }^{17}$

Population data is from the US Census Bureau and measured in persons. For years after 1970, the bureau reports yearly county level population estimates, but prior to 1970 the Bureau only reports population counts with the decennial Census. For years 1945, 1954, 1959, and 1964, we linearly impute county level populations using the two bracketing decennial census counts as end points.

\footnotetext{
${ }^{16}$ Seventy, sixty and sixty pounds are the commercial weight of corn, wheat and soybean bushels respectively.

${ }^{17}$ Only one county-year (Walton-2007) in the sample does not have a value for the rainfall variables.
} 
We use GIS shape files to calculate acreage of federal lands such as military bases or national forests. We obtain shape files for military bases from the National Transportation Atlas Database and shape files for nations preserves (forests, wet lands, etc.) from the U.S. Forestry service. To create the amount of government land per county, we intersect these shape files with county level maps and aggregate acres to the county level.

We define county types based on MSA classification status in 1950 and 2007. County types are rural, transition, or urban where a transition county is one that was not in an MSA in 1950 but is in one in 2007. Rural counties are never in an MSA and urban counties are always in an MSA. Figure 4 contain maps of Georgia where urban counties are in white, transitory counties are cross-hatched and rural counties are gray.

\subsection{Summary Statistics}

Panel A of Table 2 contains summary statistics for the pooled observations over the sample period. Across all years, counties in Georgia averaged 548 farms, 98,000 acres of agricultural land, 136,000 acres of non-agricultural land, 34,837 people and 8.89 million dollars in crop revenue. The average number of interstate highway miles per county is 4.63, but the average number of miles in the 1947 NSIH is 3.99. The differential arises because some counties contain interstates not in the original plan. If the sample is restricted to counties with positive interstate highway mileage, the average increases to 18.02 miles. The variance is extremely large suggesting that the distribution of interstates is not even across the state. In 2007, sixty-five counties contained a portion of one or more interstates.

Panel B of Table 2 contains the mean of the key economic variables for the first and last year of observation as well as the percent change between the first 
and last years' means. The average county contained more non-agricultural land in 2007 than in 1945, and the percent change in average non-agricultural land is 93.53 percent. Following this trend, there is a large drop in the average number of farms per county and a average farm revenue from crop sales. Finally the average population per county experienced a jump of almost 200 percent. The average population per county in 1945 is 20,638 and by 2007 it is 59,884 , an increase of approximately 40,000.

Panels A, B and C of Table 3 display interstate highway statistics for urban, transitory and rural counties respectively. Comparing statistics across county types reveals that urban, transitory, and rural counties received twenty-four percent, forty-six percent and thirty-one percent of all interstate highway miles respectively. However, not all counties are the recipient of an interstate as twenty percent of all urban counties, forty-four percent of all transitory counties, and seventy-six percent of all rural counties did not receive any interstate highways. The difference between actual interstate miles and 1947 NSIH miles varies significantly by county type. Rural counties received fourteen miles that are not in the 1947 NSIH while transitory counties received eighty-seven and urban counties received 106 miles respectively. While the interstate highway system is spread fairly evenly throughout the state, areas receiving miles not in the $1947 \mathrm{NSIH}$ are primarily urban and transitory counties. The Atlanta MSA contains a large concentration of interstate highway miles not in the $1947 \mathrm{NSIH}$, which includes the sixty-one mile beltway around Atlanta.

\section{Results}

Table 4 presents estimated coefficients from specifications investigating the impact of interstate highways on land use. Columns (1) through (4) contain 
estimates across all counties but include different combinations of year and county dummy variables. The base model contains neither year nor county indicators, and the full model contains both year and county dummies. The second and third columns present estimates with only year or county indicators respectively. Columns (5) through (8) present the results from our strategies to correct for endogeneity.

The opened interstate highway miles variable is positive across the first four specifications indicating that higher levels of opened interstate mileage is associated with more agricultural land loss. The estimate is statistically significant at the one percent level in columns (1) and (3), at the five percent level in column (4) and not statistically different than zero in column (2). Estimates from column (4) show that an additional mile of interstate highway leads to the conversion of 468.1 acres of agricultural land.

Estimated results from our first strategy to correct for endogeneity bias are reported in column (5). This specification includes 1947 NSIH miles instead of opened interstate miles. The estimate is positive and significant at the one percent level. Each additional mile of opened interstate highway in the 1947 NSIH plan leads to the conversion of 558.1 acres of agricultural land. This magnitude is larger than the estimate for interstate miles in column (4), but Wald tests show that the estimates are not statistically different.

Estimates in Table 5, which reports first stage regression estimates for our instruments, reveal a strong correlation between our instruments and opened interstate highway miles. The coefficients for opened interstate highway miles are 1.058, 1.069 and 1.056 when we use open $1947 \mathrm{NSIH}$ interstate miles, $1947 \mathrm{NSIH}$ plan miles multiplied by the state fraction of open 1947 NISH miles and the change opened interstates miles in the 1947 NSIH as instruments respectively. 
These estimates indicate that each additional opened mile included in the 1947 NSIH is correlated with 1.056 to 1.069 miles of opened interstate highway. Each estimated coefficient is significant at the one percent level. For each specification, the F-statistic is well above the rule of thumb level of ten suggesting that each instrument is relevant. Results from the second stage of the IV regressions are presented in columns (6)-(8) in Table 4.

Across the three IV regressions, the estimate for predicted opened interstate highway miles is positive indicating that additional interstate highway construction leads to additional agricultural land loss. The estimates in columns (6) and (7) is significant at the five percent level while the estimate in column (8) is significant at the one percent level. The magnitude of each coefficient is similar in magnitude with the OLS estimate in column (4). Wald statistical tests comparing each IV estimate to the full OLS estimate reveal that each is statistically the same as the full model estimate.

We test for regressor endogenity for both instruments using the DurbinWu-Hausman test instead of the regular Hausman test since we suspect heteroskedastic standard errors. The F-statistics is 0.854 for the specification in column (6), 3.48 for column (7) and 0.3 for the specification in column (8). In all three cases, we cannot reject the null hypothesis and conclude that the opened interstate highway miles variable is not an endogenous regressor. Based on this evidence we conclude that the OLS and IV estimates are the same.

The estimated coefficients from the IV specifications follow a trend observed in the literature in which the IV estimates using the 1947 NISH are larger in absolute value than the OLS estimates (Baum-Snow 2007a; Michaels 2008; Duranton and Turner 2011). Following Baum-Snow's (2007a) argument, we note that the gap is likely attributable to the fact that the transportation 
network is not correctly specified in our model. More specifically, other changes in the non-interstate road network are relevant when considering changes in nonagricultural land since these changes also lower transportation costs. These noninterstate roads are omitted from the specifications, and since they are likely correlated with the 1947 NSIH plan they can create omitted variable bias. ${ }^{18}$ The omitted variable bias inflates the IV estimates since the instruments will pick up influences of changes in the unobserved road network on changes in nonagricultural land. Nonetheless, we believe that the similarities between the IV and OLS specifications highlight the robustness of the magnitude of the relationship between interstate highways and land conversion.

Estimates of control variables have expected signs in the full model and are significant at the ten percent level. These results indicate that counties with an increase in population experience a decrease in acreage of agricultural land. The population coefficient in column (4) is interpreted as each additional person converts 0.0454 of acres agricultural land or the addition of a family of five to a county requires 0.227 acres of non-agricultural land to live. The results also indicate that counties that experienced a large increase in revenue from crop sales did not experience a large conversion of agricultural land or those counties that experienced a loss in crop revenue did experience high conversions of agricultural land. Each additional thousand dollars of revenue prevents the conversion of 0.978 acres of agricultural land or an additional $\$ 10,000$ in revenue conserves 9.78 acres. Our results indicate that rain fall is significant predictor of agricultural land change in Georgia. However, the estimate associated with the rain fall variable is not consistent across all specifications.

\footnotetext{
${ }^{18}$ Given the limited access design of interstate highways, commuting trips along interstates must use the underlying road network to get from the beginning destination and to the final destination.
} 
In addition to land conversion, we experimented with using population growth as a dependent variable. Estimating the effect of the interstate highways on population change examines one possible mechanism through which interstate highways effect land conversion. ${ }^{19}$ These results show that interstates have a sizeable impact on county population growth, with an additional mile of interstate highways leading to as much as a 2,376 person increase in the population. Unfortunately, the magnitude of the relationship between interstates and population is somewhat inconsistent across specifications, with IV results suggesting as little as a 196 person increase in the population from an additional highway mile.

\section{1: Robustness Check Estimates}

Table 6 presents estimates for our OLS and IV specifications when we restrict the control group to only those counties in Georgia that border a county with interstate highway mileage. Both OLS and IV estimates for interstate highway miles are positive and statistically significant. Estimates in columns (4)(6) are significant at the ten percent level while estimates in columns (7) and (8) are significant at the five and one percent level respectively. The estimate for the full model in column (4) shows that each additional highway mile leads to the conversion of 407 acres of agricultural land. Estimates from the IV regressions in column (6)-(8) are slightly larger in magnitude but not statistically different from the full model estimate.

The estimates for interstate highway miles in Table 6 are consistently smaller in magnitude than the corresponding estimates in Table 4 by, on average, sixty-six acres. Smaller coefficients are expected given the smaller sample size

\footnotetext{
${ }^{19} \mathrm{We}$ would like to thank an anonymous referee who noted this relationship and suggested this extension. Results of population regressions are available upon request.
} 
that resulted from discarding some observations. Wald statistical tests show that the estimates in Table 6 are not statistically significant from the estimates in Table 4. Based on this evidence, we conclude that the estimates in table 4 are not sensitive to unobservable differences when the treatment group contains all counties in Georgia versus when the treatment group only contains those counties bordering a county with interstate mileage.

\subsection{Estimates For Heterogeneous Impacts Across County Types}

Table 7 presents estimates for models investigating the impact of interstates on land use across different county types. ${ }^{20}$ Column (1) contains estimates from our preferred model while columns (2), (3), and (4) contain estimates for rural, transition, and urban counties respectively. Across the board, the presence of interstate highway miles increases the acreage of non-agricultural land, but the significance and magnitude varies by county type. The estimate for urban counties is significant at the five percent level while the estimates for transitory and rural counties are not significant. This shows that the relationship between highways and land use is primarily driven by what happens in urban areas. Additionally, the magnitude of the interstate highway miles estimate is seventy percent larger for urban counties than the full model. Estimated coefficients for control variables differ by county type and this is most likely attributed to the different economic forces acting in each county. Population growth is a significant predictor of decreasing levels of agricultural land in transitory counties but not in rural or urban counties. On average, transitory counties experience larger population growth that rural and urban counties (see Panel A, Figure 4), and this can explain the difference in magnitude and

\footnotetext{
${ }^{20}$ We also estimate the preferred model by initial population quartile and by initial number of farms in quartiles and find no statistically significant results.
} 
significance of the population coefficient across county types. Estimates for crop revenue are negative across all models and statistically significant at the one percent level for urban and transitory counties. The magnitude of coefficients for crop revenue in urban and transition counties indicates these counties experienced large losses in agricultural acreage as a result of declining crop revenue. The most likely explanation for this observation is that the opportunity cost for land rose above the agricultural rent causing land owners to convert to other uses to capture higher profits.

\section{Simulations}

The state of Georgia, especially the Atlanta metropolitan region, experienced large amounts of agricultural land loss from the interstate highway system. However, the system is not as large as it could have been, as several proposed interstates were never built and one new interstate is being considered. We use the estimates from equation (1) to predict changes in the amount of nonagricultural land in response to four proposed highway expansion projects: 1) construction of the Outer Perimeter, 2) construction of the Northern Arc, 3)

construction of the $14^{\text {th }}$ Amendment Highway and 4) if interstate highway miles in Georgia are doubled. Figure 7 shows the proposed interstate highway routes and Georgia's existing interstate.

\subsection{Proposed Highways}

\subsection{A The Outer Perimeter and the Northern Arc}

The "Outer Perimeter" is a planned expressway encircling the Atlanta metropolitan area that lies approximately twenty miles outside of I-285. There are two proposed alternatives, that we name Alternatives A and B, which differ only in their routes south of Atlanta. Figure 8 maps the different sections of the Outer 
Perimeter. ${ }^{21}$ The Northern Arc is the double white and black dashed line (55.67 miles), eastern and western arcs are double lines (46.76/44.1 miles) and the southern arc is shaded in gray for Alternative A (61.1 miles ) and in black dashed lines for alternative B (84.4 miles). The total length of the Outer Perimeter using Alternative A is 213.32 miles and using Alternative B is 236.36 miles. $^{22}$ No sections of the Outer Perimeter coincide with previously existing interstate highway routes. The state of Georgia did not meet the National Air Ambient Quality standards set by the Clean Air Act of 1990 and therefore the Georgia Department of Transportation scaled back the Outer Perimeter by proposing only the Northern Arc (Georgia State University and Research 2000). This section of highway would provide a direct link between six major highways that service Atlanta's northern area: I-75, I-575, Georgia 400, I-985, I-85 and Georgia 316.

Our simulations assume the full impact of either the opening of the Outer Perimeter or the Northern Arc is captured fully by variables in the year 2007. We also assume that no sections of the Outer Perimeter and Northern Arc are opened before 2007. These assumptions are quite safe, given that we only know the project proposal dates or proposed construction dates, the actual construction did not occur and interstate highway construction requires a long time to complete.

Simulation results for the Outer Perimeter and Northern Arc are given in Table 8 and shown graphically in Figure 8. Construction of alternative A of the Outer Perimeter causes the loss of 98,232 acres of agricultural land spread out along the length the route. Counties that experience the highest percent change in non-agricultural land are Henry, Bartow, and Rockdale counties at 5.68 percent,

\footnotetext{
${ }^{21}$ We digitize a map from the Atlanta Regional Commission published in the Atlanta Journal Constitution to create highway miles needed for the simulation (Goldberg 1994)

${ }^{22}$ The key differences are what counties the routes cross and the miles in each county. Alternative A contains 10.82, 17.94, and 17.73 miles in Fayette, Coweta, and Spalding counties respectively. Alternative B contains zero miles in Fayette County and 31.9 and 23.61 miles in Coweta and Spalding respectively.
} 
5.80 percent and 5.57 percent respectively. Construction of Alternative B leads to a loss of 109,020 acres of agricultural land which is 10,788 more acres more than Alternative B. However, this result is not surprising since Alternative B is twenty-three miles longer. Since Alternative B runs along a different route, the predicted change in non-agricultural land changes as well. Coweta and Spalding counties both experience over a 5,000 acre increase in non-agricultural land in Alternative B relative to Alternative A while Carroll, Butts, Lamar, and Pike counties experience smaller increases. Fayette, Polk, Fulton and Douglas counties preserve more agricultural land if Alternative B is constructed over Alternative A.

Figure 8 and Table 8 also report results for the Northern Arc simulation.

A total of 26,061 acres of agricultural land is converted to other uses as a result of construction. Cherokee county experiences forty-three percent of the conversion by losing over 10,000 acres of agricultural land.

\subsection{B $14^{\text {th }}$ Amendment Highway}

On August 10, 2005, Congress passed the "Safe, Accountable, Flexible, Efficient Transportation Equality Act (SAFETEA) and section 1927 required the FHWA to study the construction of a route linking Natchez, Mississippi to Augusta, Georgia (Safe, Accountable, Flexible, Efficient Transportation Equality Act: A Legacy for Users 2005). This route became known as the $14^{\text {th }}$ Amendment highway and connects Natchez to Augusta via Montgomery, Alabama, Columbus, Georgia and Macon, Georgia. One of the proposed alternatives for the new routes requires all roads along the route meet full interstate standards. Under this alternative ninety-seven miles of existing roads would be upgraded to full interstate design standard and 178 miles of new interstate will be constructed. 
Figure 7 contains a map of the $14^{\text {th }}$ Amendment Highway, represented by the black and white dashed line, which we digitize from a map at the FHWA website. $^{23}$ The interstate is approximately 200 miles long and crosses sixteen counties on its route from Columbus to Augusta. It intersects four existing interstates (I-185, I-75, I-16 and I-20), and two sections coincide with existing interstates. $^{24}$

We use 2007 as our year for prediction since Congress passed the law in 2005. Our simulation assumes that the interstate highway is constructed and completely opened by 2007. Table 9 contains the counties that receive a segment of the highway, the interstate mileage, the predicted amount of non-agricultural land without the highway and the predicted amount of non-agricultural land with the highway. 79,358 acres of agricultural land are converted as a result of the construction of the $14^{\text {th }}$ Amendment interstate. Richmond, Columbia, and Bibb counties convert less agricultural land than other counties along the route primarily because even though they contain mileage on the route, the mileage is part of a previously existing interstate. Crawford and Hancock counties experience the most converted agricultural land with each county having over 9,000 acres converted. Warren and Crawford counties experience the largest percent change in non-agricultural land and 5.58 percent and 5.72 percent respectively. Figure 9 contains the $14^{\text {th }}$ Amendment Highway and the percent change in non-agricultural land represented by columns. The figure shows that the construction of the highway leads to a conversion of agricultural land along its

\footnotetext{
23 The map can be found at http://www.fhwa.dot.gov/planning/section_1927/14th_amendment_highway/study_alignments/ ${ }^{24}$ The first section runs for 12.74 miles along I-75 and I-16 in Macon and the second section runs for 17.82 miles along I-20 near the city of Augusta.
} 
entire path. On average, a county that lies in its path experiences a 3.11 percent increase in non-agricultural land.

\subsection{Expanding or Contracting the Existing Footprint of Highways}

We use our model to predict what would happen if highways are constructed fifty percent larger and fifty percent smaller, but retain their current route. In order to fully investigate the impact, we examine the change in interstate highway mileage at three unique points in time. The first point, 1969, represents the state of Georgia during the highway building period and the second, 1982, represents the state at the conclusion of the highway building period. The investigation of 1982 is of particular interest since it provides insights into what would have happened if the original interstate highway system in Georgia was designed on a grander or smaller scale. The final point, 2007, represents the most recent observations of the state and captures the construction of several auxiliary interstates.

Figure 10 contains three maps corresponding to each year of the simulation: 1969, 1982, and 2007. Vertical bars on the maps represent the increase in the acreage of non-agricultural land that results from the additional interstate. We overlay each map with the completed interstate highways at that time. The figures show that increasing the mileage of interstate highways leads to a further loss in the acreage of agricultural land but only in counties containing open interstates. Counties that receive more interstates experience a larger loss. The results for a fifty percent decrease in the mileage of interstate are symmetric to the fifty percent increase. If the interstate highway system were built half as large then the interpretation of the columns is the amount of agricultural land preserved. In this case, there is more preservation agricultural land across the 
state and especially in counties receiving a high number of interstate highway miles.

Figure 11 presents the aggregate percent change in the state total of nonagricultural land as a result of a fifty percent increase or decrease in the number of highway miles. At the beginning of the highway building period, doubling or halving the number of miles had little impact. As time progresses through the period, the impact grows to approximately a one percent increase or decrease in the amount of non-agricultural land. If the interstate highway system experienced a fifty percent increase Georgia would lose 2.6 million acres of agricultural land and if the state experienced a fifty percent decrease in highway the state would preserve 2.6 million acres.

\section{Conclusion}

Our regression results provide evidence that the construction of interstate highways drives the conversion of agricultural land to urban uses within Georgia. Our preferred estimates show that the lower bound for agricultural land loss that results from the construction of each additional mile of interstate is 468 acres. The impact of interstate highways on agricultural land loss is largest for urban counties and non-existent in rural and transitory counties. Simulation results demonstrate that any planned expansion to the interstate highway system results in additional agricultural land conversion. We also show that if the original interstate highway system were built half as large, 2.6 million acres of agricultural land would have been preserved.

Loss of agricultural land is not a trend isolated to the state of Georgia, but rather a problem occurring across the nation. The economic actors, especially the interstate highway system, that influence agricultural land conversion in Georgia 
may be influential in other states. Given our conclusion that new interstate highways contribute to agricultural land conversion, future conservation programs may want to consider how to mitigate their impact. While some strategies focus on urban growth boundaries, zoning laws, state growth management plans, or building permit limits, our results suggest that it is important to consider the impact of the interstate highway system. 


\section{References}

AASHTO (2005) A Policy on Design Standards--Interstate System. American Association of State Highway and Transportation Officials.

Alonso W (1964) Location and Land Use. Harvard University Press, Cambridge, MA.

Baum-Snow N (2007a) Did highways cause suburbanization? Quarterly Journal of Economics 122 (2):775-805.

Baum-Snow N (2007b) Suburbanization and transportation in the monocentric model. Journal of Urban Economics 62:405-423.

Chandra A, Thompson E (2000) Does public infrastructure affect economic activity?: Evidence from the rural interstate highway system. Regional Science and Urban Economics 30 (4):457-490.

Davis SC, Diegel SW, Boundy RG (2011) Transportation Energy Data Book, vol 30. Oak Ridge.

Duranton G, Turner MA (2011) The Fundamental Law of Road Congestion: Evidence from US Cities. American Economic Review 101 (6):26162652.

Duranton, G. and M.A. Turner (2012). Urban Growth and Transportation. The Review of Economic Studies

Georgia Department of Transportation (1981) Annual Report for Fiscal Years 1979-1981. Atlanta.

Georgia Department of Transportation (1989) Fiscal Year 1989 Annual Report. Atlanta.

Georgia State University AYSPS, Research A (2000) The northern arc: the outer perimeter reincarnated? Research Atlanta, Inc.

Goldberg D (1994) Loop appears dead; portion looks likely. Atlanta Journal Constitution, November 20, 1994.

Lavingo B, Dorfman J, Barnett B, Bergstrom J (2004) Farmland preservation in Georgia: three possible roads to success. University of Georgia.

Michaels G (2008) The effect of trade on the demand for skill: evidence from the interstate highway system. Review of Economics \& Statistics 90 (4):683701.

Mills ES (1967) An Aggregative Model of Resourse Allocation in a Metropolitan Area. American Economic Review 57:197-210.

Muth RF (1969) Cities and Housing. University of Chicago Press, Chicago.

Nechyba TJ, Walsh RP (2004) Urban Sprawl. Journal of Economic Perspectives 18 (4):177-200.

Safe, Accountable, Flexible, Efficient Transportation Equality Act: A Legacy for Users (2005). 109-59. Washington D.C.

U.S. Department of Agriculture NASS (2011) Crop Production Historical Track Records. Washington.

U.S. Department of Transportation FHWA (1980-2008) Highway Performance Monitoring System. Washington.

U.S. Department of Transportation FHWA (1993) Status of Improvement of the National System of Interstate and Defense Highways File PR-511.

Washington.

U.S. Department of Transportation FHWA (1995) Comprehensive Truck Size and Weight Study Summary Report for Phase I--Synthesis of Truck Size and Weight (TS\&W) Studies and Issues. http://ntl.bts.gov/DOCS/cts.html. 
U.S. Department of Transportation FHWA (2010) Highay Performancing Monitoring System Field Manual. Washington.

U.S. Department of Transportation FHWA (2011) The Dwight D. Eisenhower System of Interstate and Defense Highways-- Engineering Data.

http://www.fhwa.dot.gov/highwayhistory/data/page00.cfm. Accessed April 52012. 
Figure 1: Georgia Interstate Highway System by Plan of Inclusion

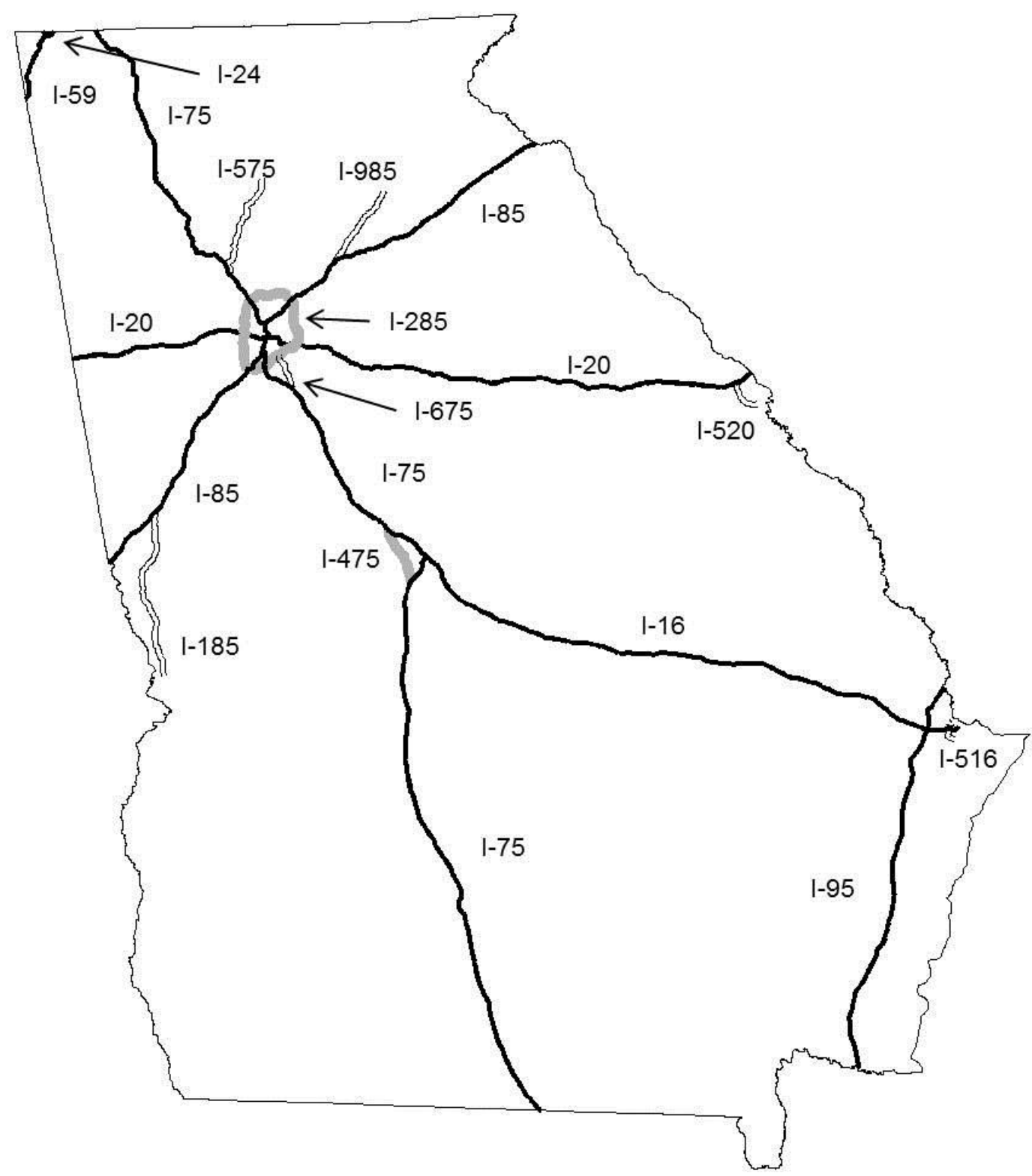

Notes: The figure shows Georgia's current interstate highway routes and segments each route according to when it was added to the system. Black lines are routes included in the 1947 National System of Interstate Highways. Gray lines are those routes added after 1947 and considered to be in Georgia's original interstate highway system. Doubled lines are addition routes to the system and were added after 1979. 
Figure 2: Opened Interstate Highway Segments by Year
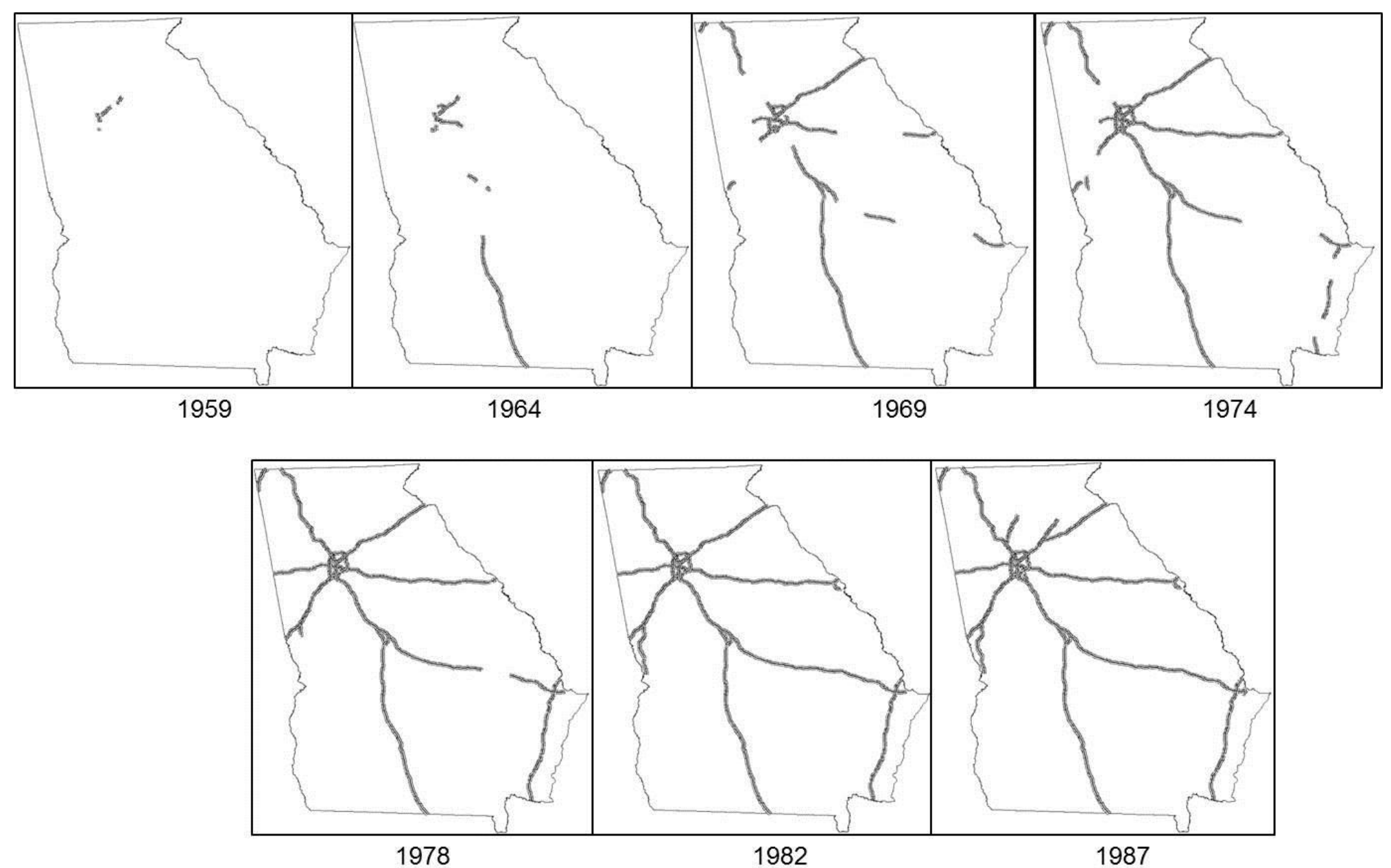

Notes: The first section of I-75 opened by 1954 and the final section of I-675 was completed in 1992; however, due to their small lengths they are not visible on full scale maps. 
Figure 3: Trends in Non-Agricultural Land, Population and Open Interstates

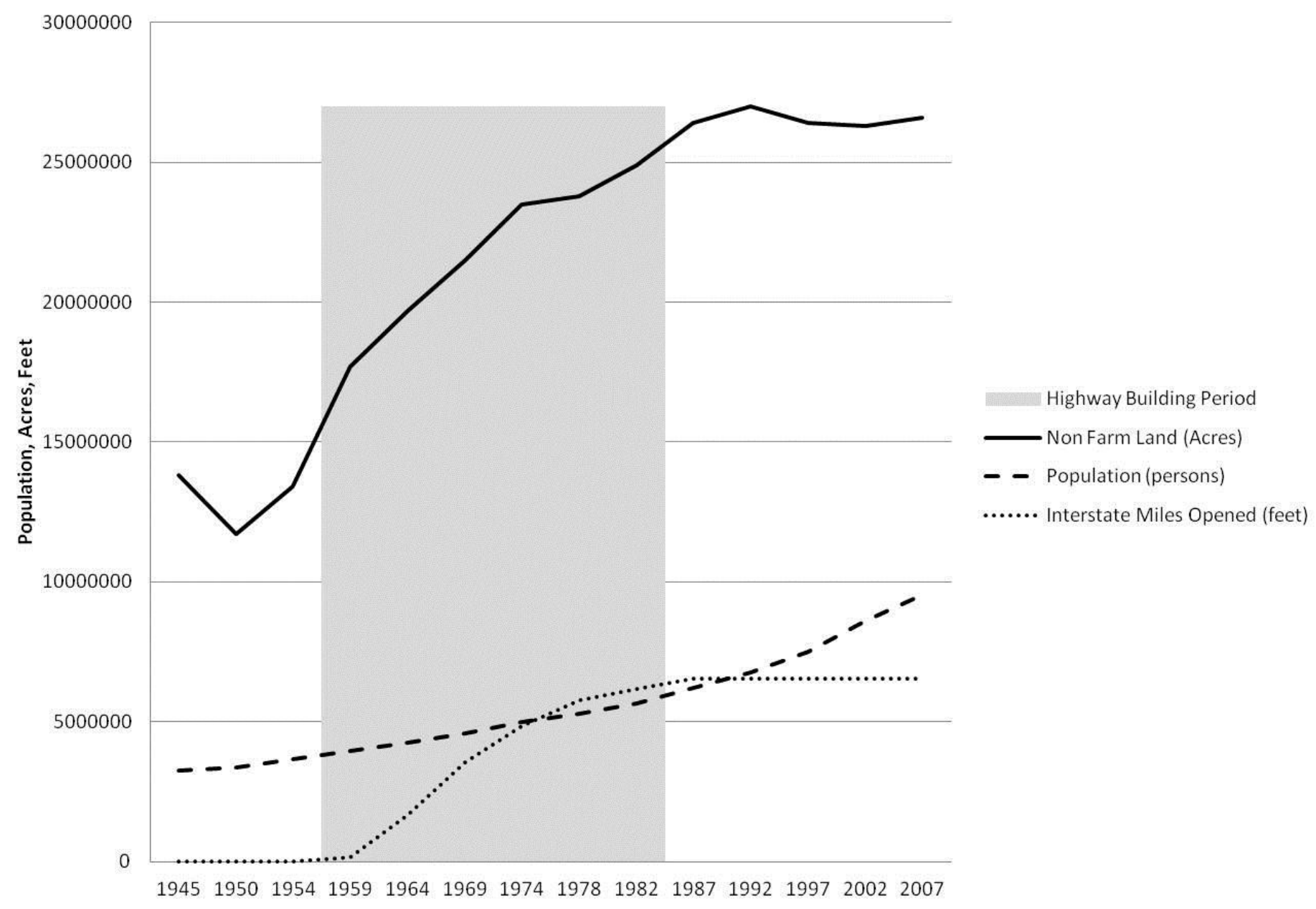


Figure 4: Interstate Highway Miles and Population Growth in Rural, Transitory and Urban Counties

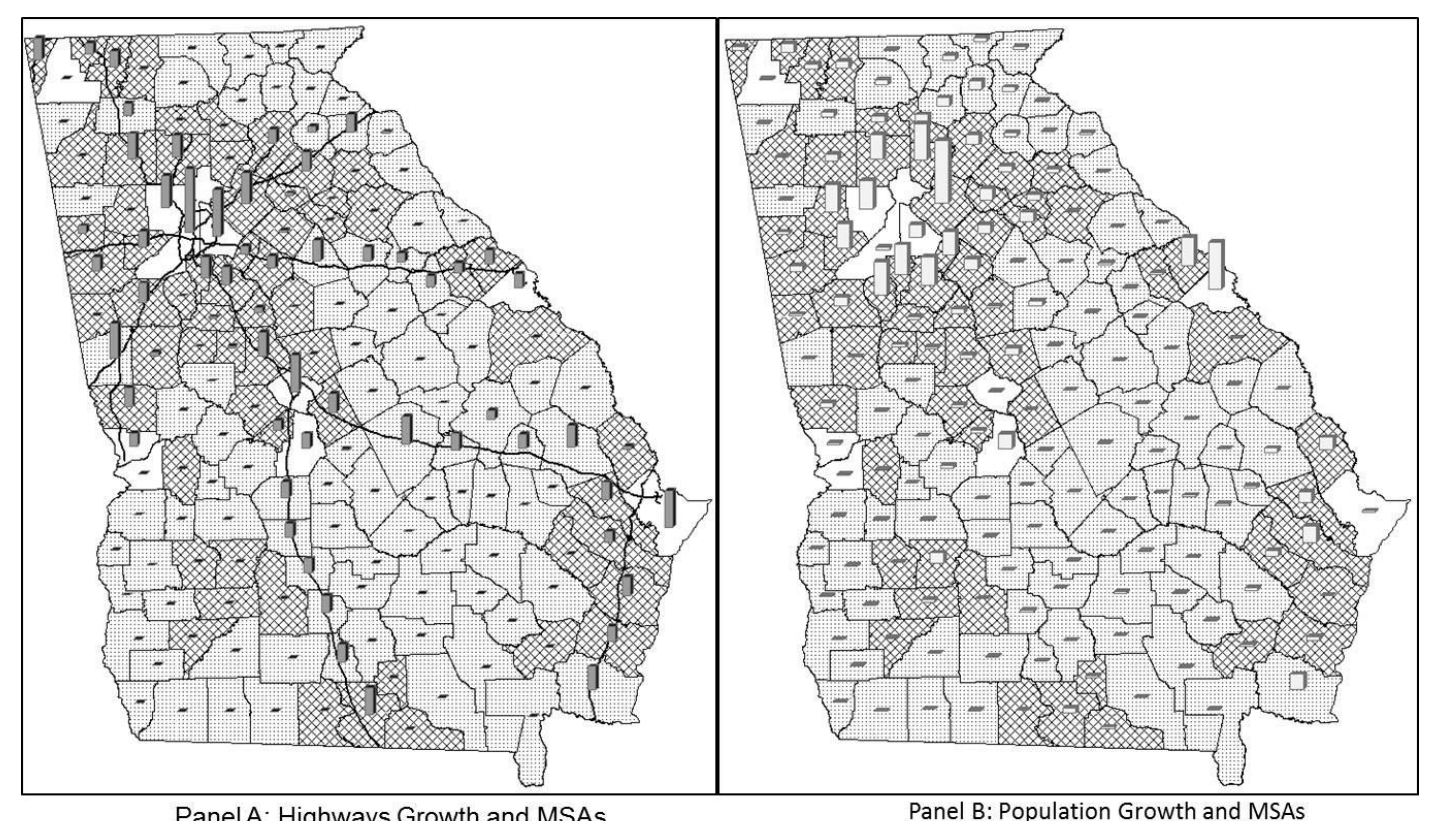

Panel A: Highways Growth and MSAs

Panel B: Population Growth and MSAs

Notes: Vertical bars in Panel A represent the number of interstate highway miles a county received over the time period 1945 to 2007 while in Panel B the vertical bars represent the level of population changes between 1945 and 2007. Urban counties are white, transitory counties are cross-hatched and rural counties are gray. 
Figure 5: Georgia Counties by Interstate Highway Inclusion

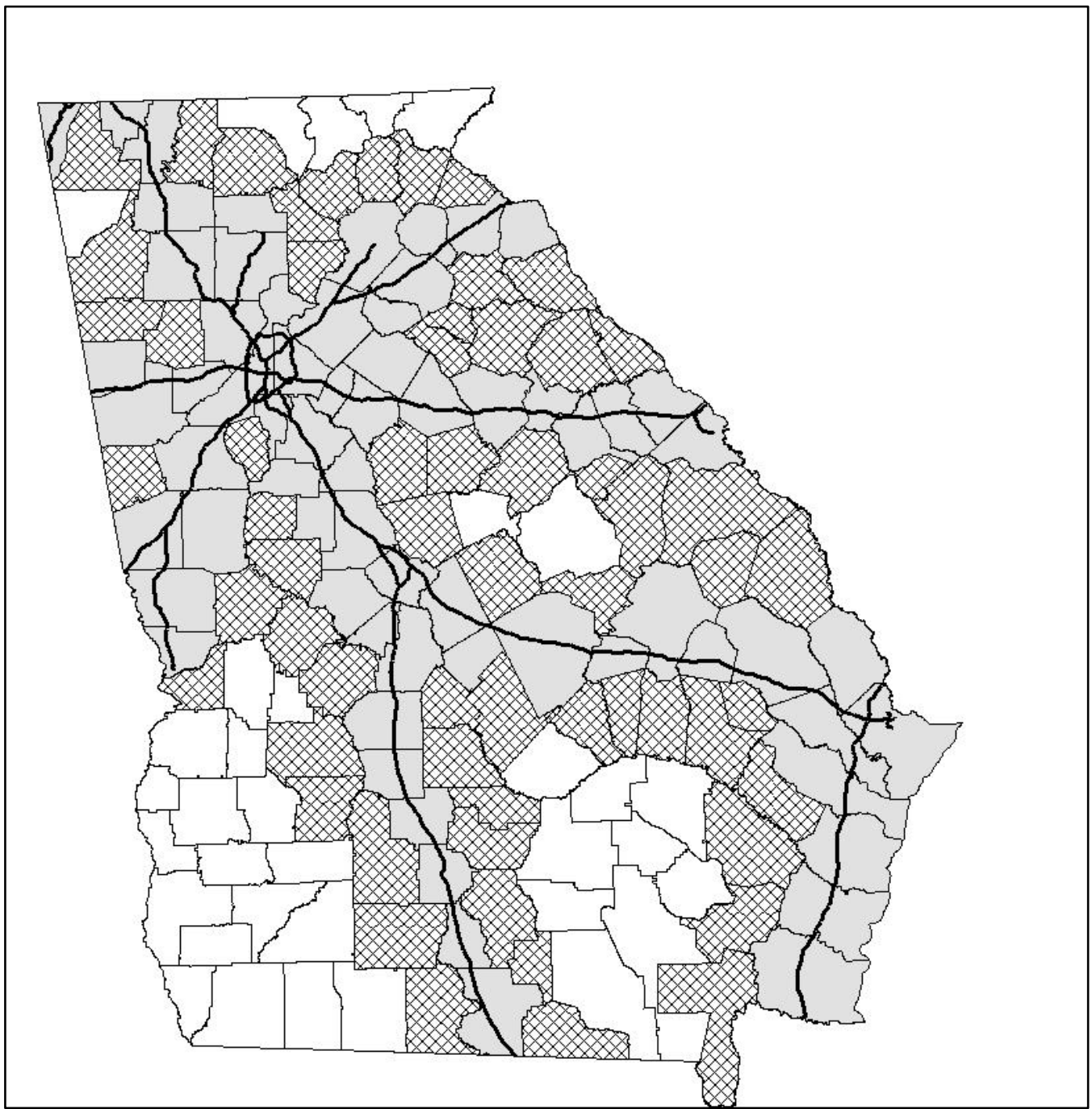

Black lines represent existing interstate highways. Counties that contain an interstate highway are shaded in gray (Category 1). Counties that border a county containing an interstate highway are cross-hatched (category 2).

Counties without interstate highway and that do not border a county containing an interstate highway are white (Category 3). Out of Georgia interstate highways are not included in the analysis. 
Figure 6: Hierarchal Structure of Land within US Agricultural Census

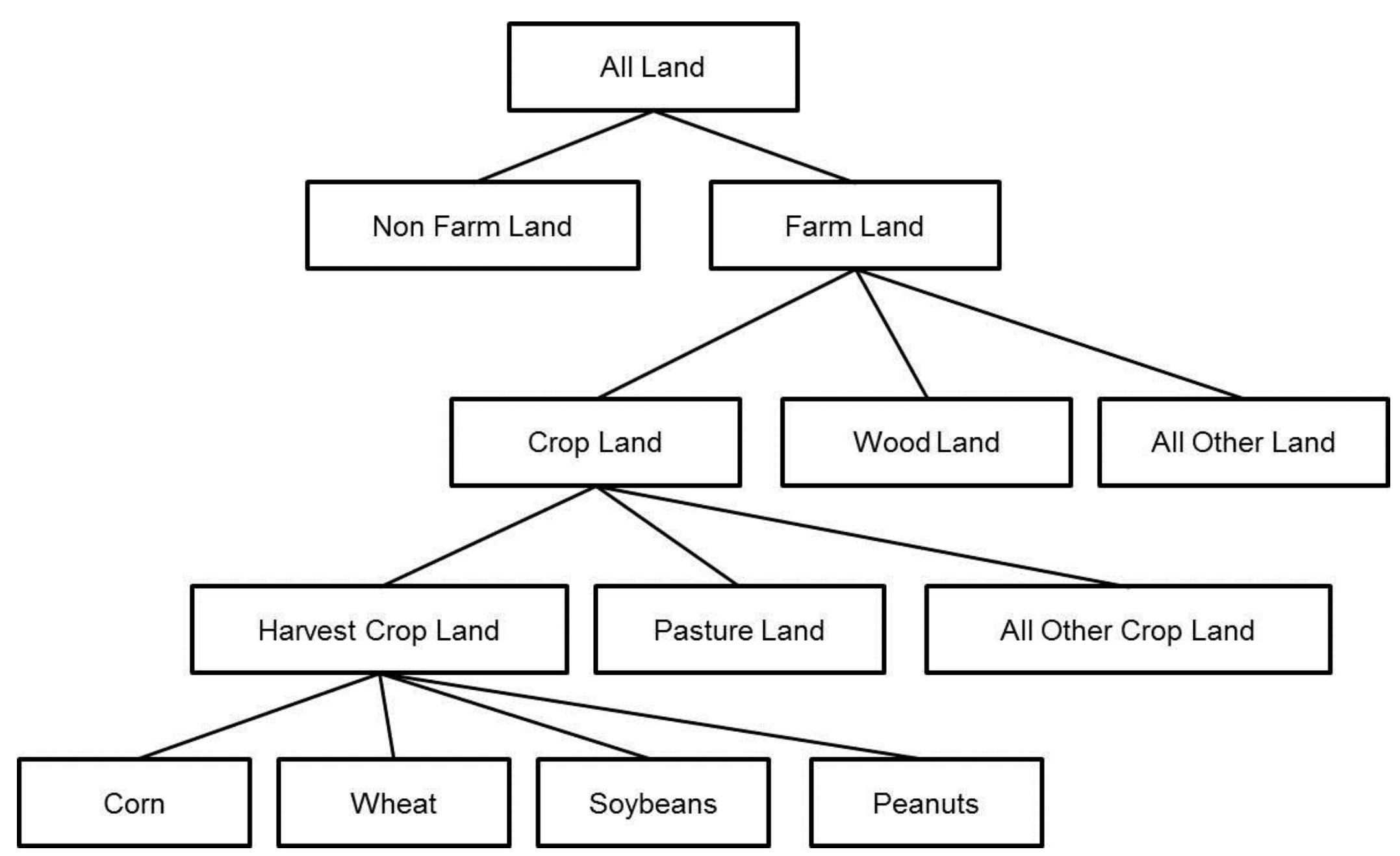


Figure 7: Proposed Interstate Highways in Georgia

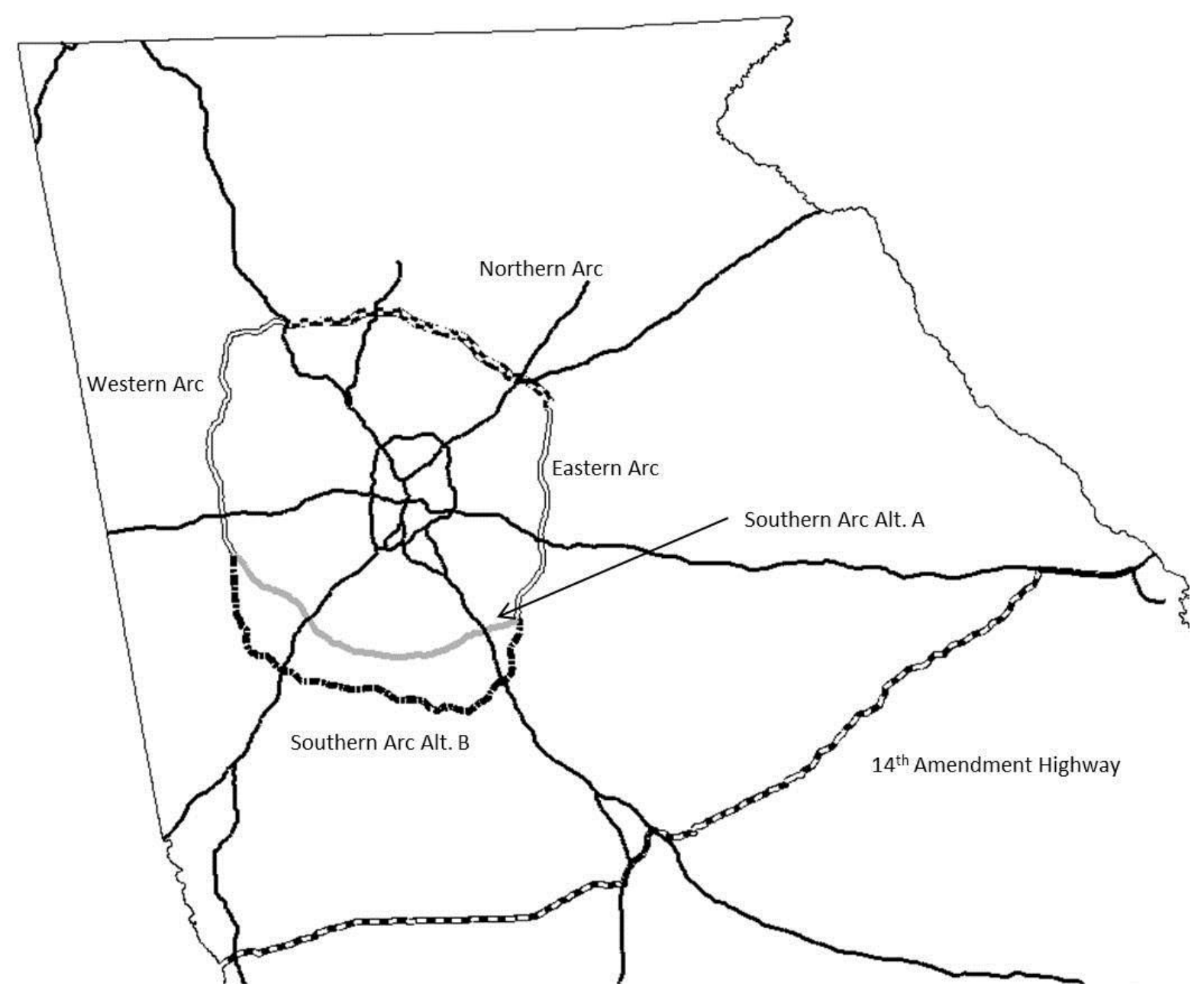

Notes: The $14^{\text {th }}$ Amendment Interstate Highway is the black and white dashed line and has two segments that coincide with existing interstates. The Northern Arc is the double white and black dashed line and the Western/Eastern Arcs of the Outer Perimeter are the double lines. Alternative A of the southern arc of the Outer Perimeter are shaded in gray while Alternative B is the black dashed lines. Existing interstate highways are shown in black. 


\section{Figure 8: Simulation Results for the Outer Perimeter and Northern Arc Interstates}

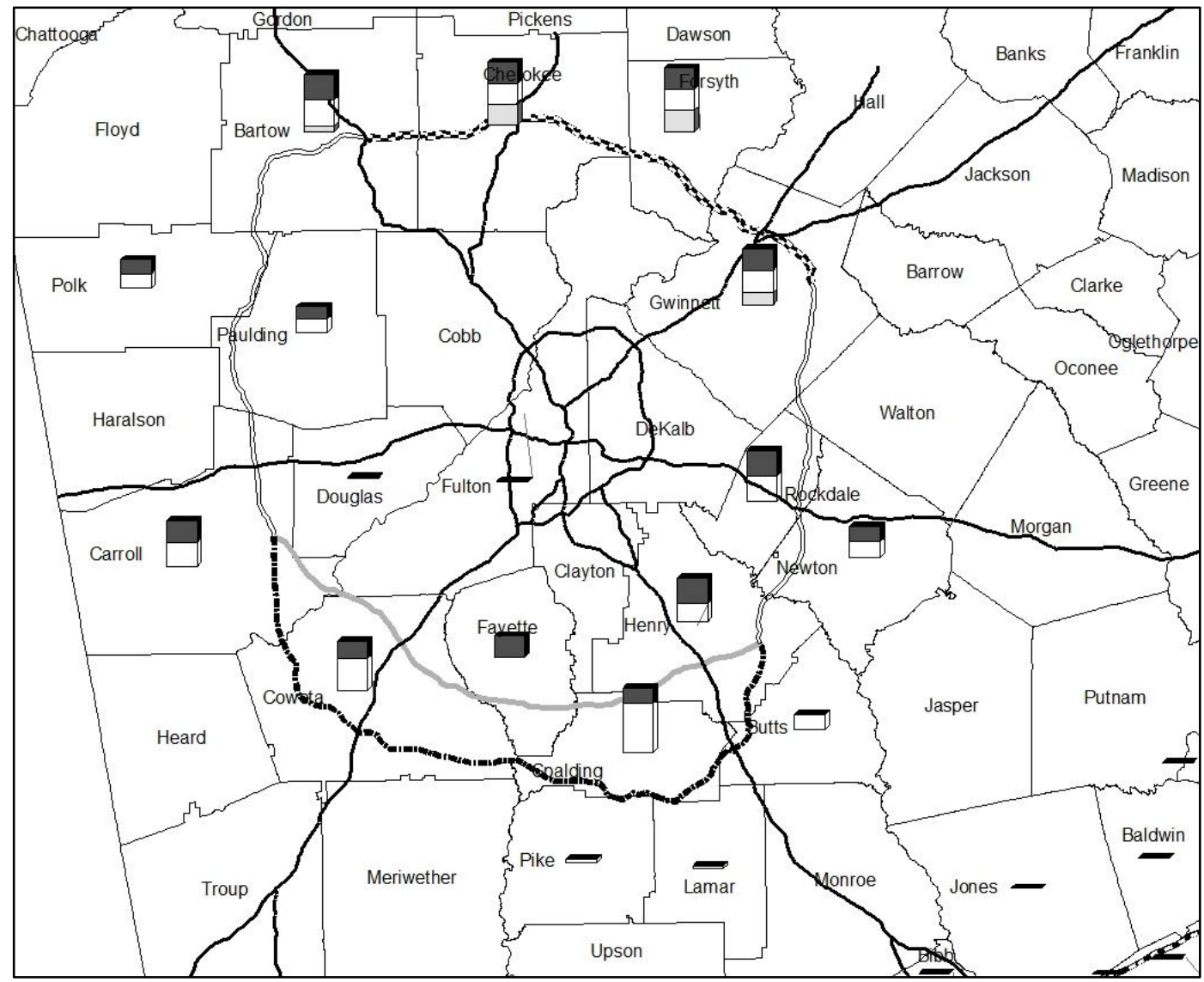

Notes: The Northern Arc is the double white and black dashed line and the Western/Eastern Arcs of the Outer Perimeter are the double lines. Alternative A of the southern arc of the Outer Perimeter are shaded in gray while Alternative B is the black dashed lines. Existing interstate highways are shown in black.

Light gray represents the percent change in non-farm land that results from the construction of the Northern Arc. Dark gray represents the percent change in nonfarm land that results from the construction of the Outer Perimeter using alternative 1 and white is from the construction of the Outer Perimeter using alternative 2 . 
Figure 9: Simulation Results for the $14^{\text {th }}$ Amendment Interstate Highway

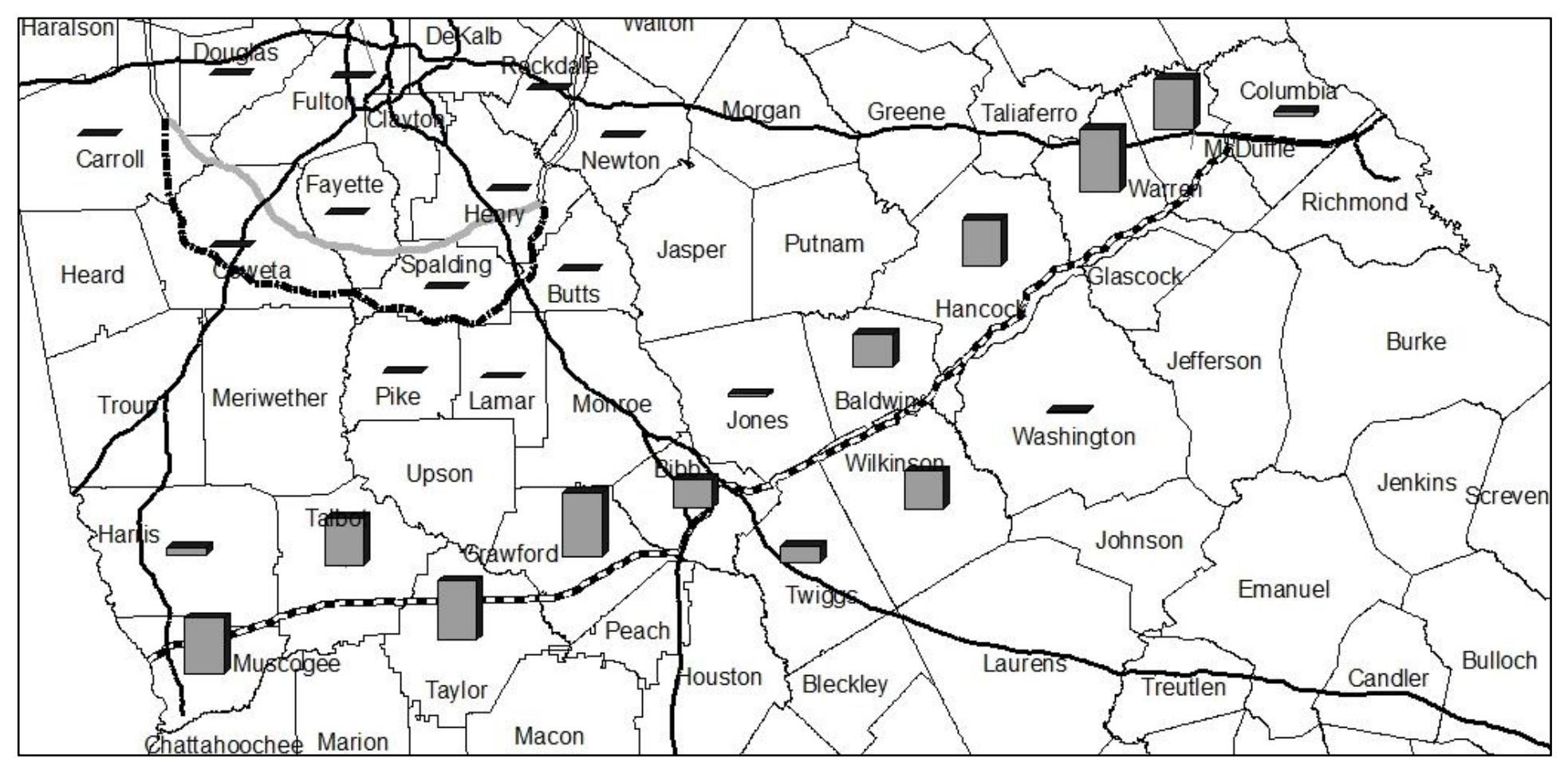

Notes: The $14^{\text {th }}$ Amendment Interstate Highway is the black and white dashed line and has two segments that coincide with existing interstates. Gray bars represent the percent change in non-farm land that results from the construction of the $14^{\text {th }}$ Amendment Interstate Highway. 
Figure 10: Simulation Results for a 50 Percent Increase in Interstate Miles

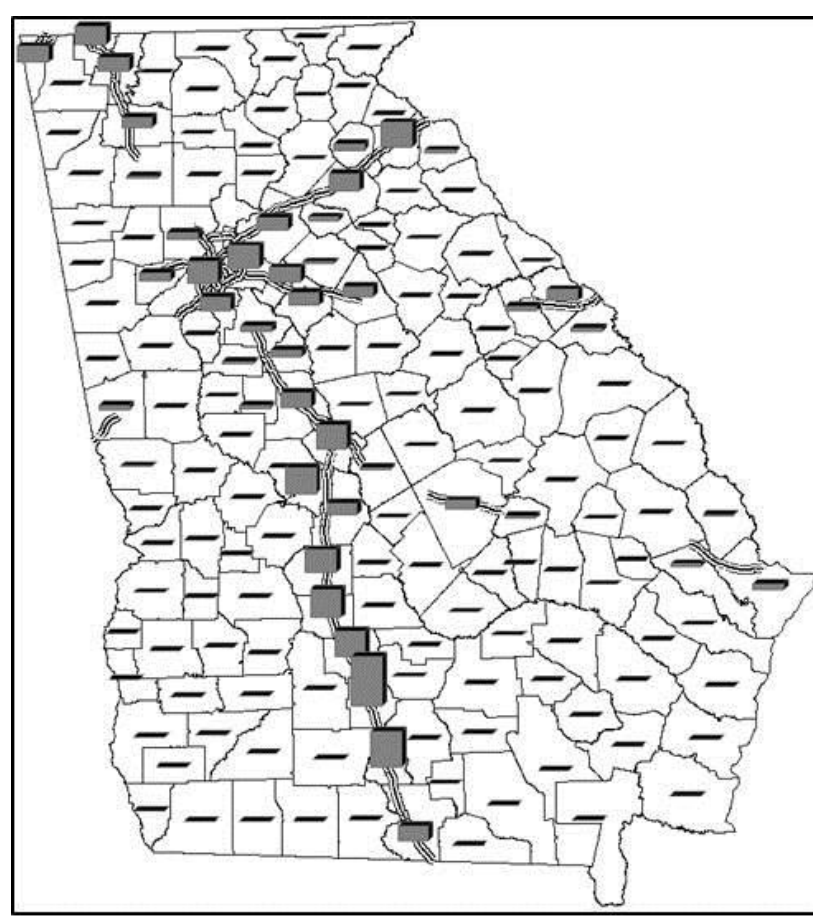

1969

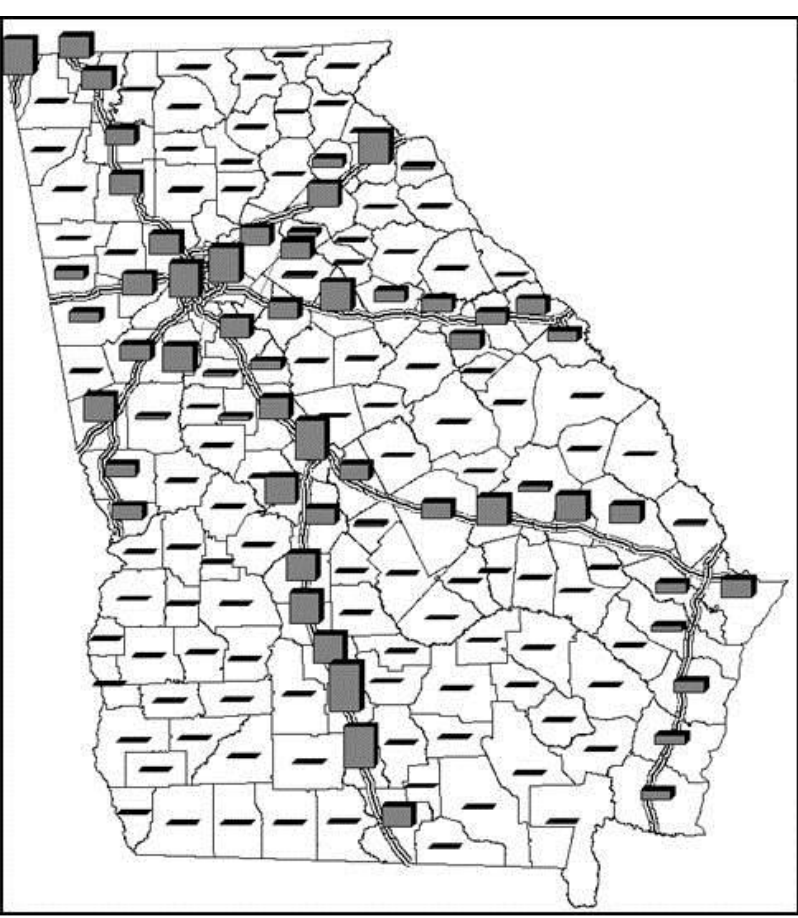

1982

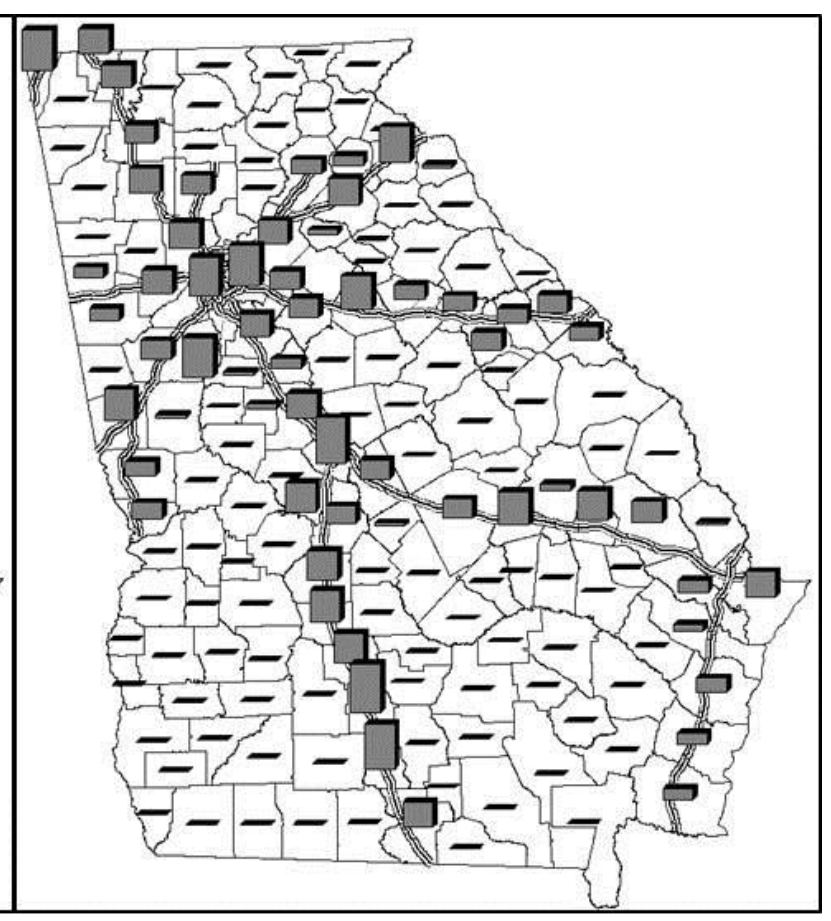

2007

Notes: Constructed interstate highways are shown black lines. Vertical gray bars represent the percent change in non-farm land as a result of a $50 \%$ increase in highway mileage. The bars also represent the amount of farm land that would have been preserved if the interstate highway system were built half as large in Georgia 
Figure 11: Simulation Results for a 50 Percent Increase and Decrease in Highway Miles

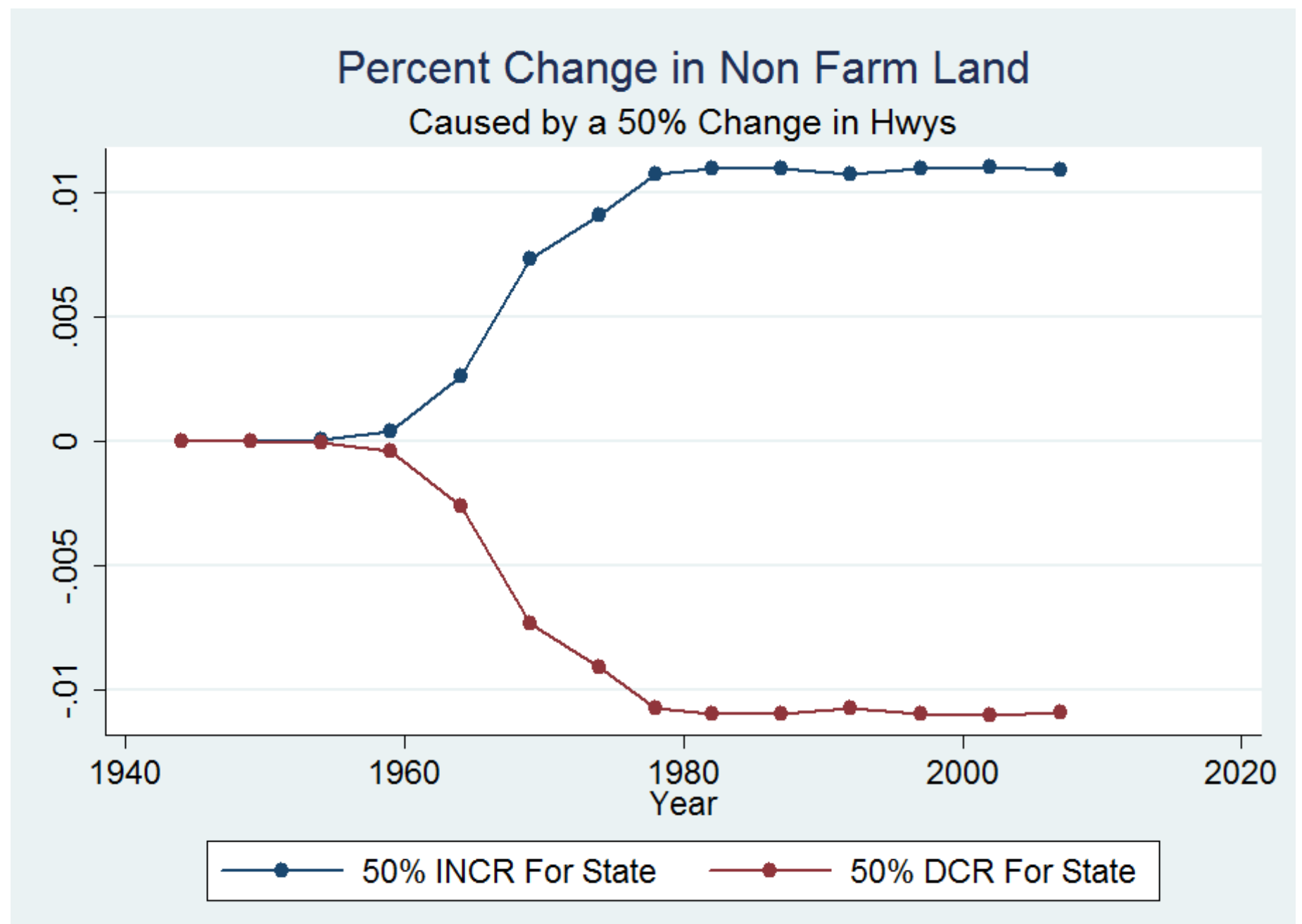


Table 1: Value of Crops Produced Relative to Aggregate Value of Crops Sold

\begin{tabular}{cccccc} 
Year & Corn & Wheat & Peanuts & Soybeans & Total \\
\hline \hline 1945 & $17.17 \%$ & $1.12 \%$ & $16.03 \%$ & $0.05 \%$ & $34.37 \%$ \\
1950 & $24.77 \%$ & $1.61 \%$ & $25.15 \%$ & $0.17 \%$ & $51.69 \%$ \\
1954 & $22.24 \%$ & $1.76 \%$ & $11.04 \%$ & $0.18 \%$ & $35.22 \%$ \\
1959 & $26.36 \%$ & $1.28 \%$ & $15.85 \%$ & $0.71 \%$ & $44.20 \%$ \\
1964 & $18.52 \%$ & $0.83 \%$ & $23.15 \%$ & $2.03 \%$ & $44.53 \%$ \\
1969 & $21.59 \%$ & $0.77 \%$ & $31.68 \%$ & $5.87 \%$ & $59.91 \%$ \\
1974 & $34.06 \%$ & $1.08 \%$ & $29.14 \%$ & $15.34 \%$ & $79.62 \%$ \\
1978 & $20.00 \%$ & $1.07 \%$ & $36.02 \%$ & $18.88 \%$ & $75.98 \%$ \\
1982 & $12.71 \%$ & $8.23 \%$ & $28.03 \%$ & $23.99 \%$ & $72.96 \%$ \\
1987 & $9.05 \%$ & $3.23 \%$ & $38.92 \%$ & $8.90 \%$ & $60.10 \%$ \\
1992 & $7.92 \%$ & $2.64 \%$ & N/A & $5.21 \%$ & $15.77 \%$ \\
1997 & $5.28 \%$ & $2.08 \%$ & N/A & $2.43 \%$ & $9.78 \%$ \\
2002 & $15.96 \%$ & $11.74 \%$ & $29.61 \%$ & N/A & $57.31 \%$ \\
2007 & $8.32 \%$ & $2.12 \%$ & $24.21 \%$ & $2.88 \%$ & $37.53 \%$ \\
\hline Value of crops sales and aggregate value of crops sold are from the U.S. Census of \\
Agriculture.
\end{tabular}


Table 2: Summary Statistics for All Variables

Panel A: Statistics Across Observations Pooled for All Years

\begin{tabular}{|c|c|c|c|c|c|}
\hline Variable & Obs & Mean & Std. Dev. & Units & Years Available \\
\hline Non-Agricultural Land & 2222 & 136202 & 87403 & Acres & All \\
\hline Agricultural Land & 2222 & 97817 & 71315 & Acres & All \\
\hline Highway Miles ${ }^{\mathrm{a}}$ & 2222 & 4.63 & 10.26 & Miles & All \\
\hline Highway Miles-Positive Values ${ }^{\mathrm{b}}$ & 571 & 18.05 & 12.99 & Miles & All \\
\hline 1947 NSIH Miles & 2222 & 3.99 & 8.57 & Miles & All \\
\hline Previous Amount of Rain fall & 2222 & 48.62 & 9.32 & Inches & All \\
\hline Population & 2222 & 34781 & 78001 & Persons & All \\
\hline Revenue & 2222 & 3957 & 5843 & $\begin{array}{l}2007 \text { Thousands of } \\
\text { Dollars }\end{array}$ & All \\
\hline Government Land & 2222 & 11241 & 31008 & Acres & All \\
\hline Farms & 2222 & 548 & 529 & Farms & All \\
\hline
\end{tabular}

\begin{tabular}{|c|c|c|c|c|}
\hline \multicolumn{5}{|c|}{ Panel B: Percent Change in Means Between 1945 and 2007} \\
\hline Variable & 1945 Mean & 2007 Mean & Percent Change & \\
\hline Non-Agricultural Land & 86641 & 167680 & $93.53 \%$ & \\
\hline Agricultural Land & 148905 & 63904 & $-57.08 \%$ & \\
\hline Highway Miles $^{\mathrm{a}}$ & 0 & 7.83 & N/A & \\
\hline Highway Miles-Positive Values ${ }^{b}$ & 0 & 19.06 & N/A & \\
\hline 1947 NSIH Miles ${ }^{\mathrm{c}}$ & 0 & 6.51 & N/A & \\
\hline Previous Amount of Rain fall & 54.47 & 40.52 & $-25.61 \%$ & \\
\hline Population & 20368 & 59884 & $194.01 \%$ & \\
\hline Revenue & 6460 & 1807 & $-72.03 \%$ & \\
\hline Government Land & 11202 & 11424 & $1.98 \%$ & \\
\hline Farms & 1420 & 300 & $-78.87 \%$ & \\
\hline
\end{tabular}

Statistics are calculated for observations that have positive values of non-agricultural land and rainfall data. Four

observations did not meet this criteria. a: Includes all counties b: Includes only counties with positive values c: the acronym

for the National System of Interstate Highways is NSIH 
Table 3: Highway Statistics for Urban, Transitory and Rural Counties by Year

Panel A: Statistics for Urban Counties ${ }^{\mathrm{a}}$

\begin{tabular}{|c|c|c|c|c|c|c|c|c|c|}
\hline Year & 1954 & 1959 & 1964 & 1969 & 1974 & 1978 & 1982 & 1987 & 1992 \\
\hline "Average Interstate Miles & 0 & 1.99 & 5.67 & 20.28 & 23.35 & 25.62 & 28.16 & 29.38 & 29.57 \\
\hline Cumulative Interstate Miles & 0 & 19.88 & 56.74 & 202.83 & 233.53 & 256.19 & 281.59 & 293.80 & 295.72 \\
\hline Cumulative 1947 NSIH Miles $^{\text {b }}$ & 0 & 19.88 & 48.06 & 148.31 & 166.32 & 188.99 & 188.99 & 188.99 & 188.99 \\
\hline Cumulative Interstates Miles not in 1947 NSIH & 0 & 0 & 8.68 & 54.52 & 67.21 & 67.20 & 92.60 & 104.81 & 106.73 \\
\hline Percent of Counties Receiving Interstate Miles & 0 & 20 & 30 & 70 & 70 & 70 & 80 & 80 & 80 \\
\hline \multicolumn{10}{|c|}{ Panel B: Statistics for Transitory Counties ${ }^{\mathrm{c}}$} \\
\hline Year & 1954 & 1959 & 1964 & 1969 & 1974 & 1978 & 1982 & 1987 & 1992 \\
\hline " Average Interstate Miles & 0.04 & 0.19 & 1.11 & 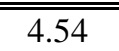 & 6.51 & 7.85 & 8.19 & \$\$9.10 & 9.10 \\
\hline Cumulative Interstate Miles & 2.46 & 11.71 & 68.73 & 281.27 & 403.4 & 486.98 & 507.69 & 564.41 & 564.76 \\
\hline Cumulative 1947 NSIH Miles & 2.46 & 11.71 & 64.14 & 271.78 & 393.92 & 477.5 & 477.5 & 477.5 & 477.5 \\
\hline Cumulative Interstates Miles not in 1947 NSIH & 0 & 0 & 4.59 & 9.49 & 9.48 & 9.48 & 30.19 & 86.91 & 87.26 \\
\hline Percent of Counties Receiving Interstate Miles & 1.61 & 3.23 & 8.06 & 43.55 & 48.39 & 56.45 & 58.06 & 58.06 & 58.06 \\
\hline \multicolumn{10}{|c|}{ Panel C: Statistics for Rural Counties ${ }^{d}$} \\
\hline Year & 1954 & 1959 & 1964 & 1969 & 1974 & 1978 & 1982 & 1987 & 1992 \\
\hline Average Interstate Miles & 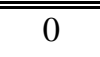 & 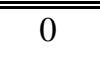 & 1.06 & 2.17 & 3.18 & 4.03 & 4.35 & 4.35 & 4.35 \\
\hline Cumulative Interstate Miles & 0 & 0 & 92.16 & 188.84 & 276.62 & 350.4 & 378.15 & 378.15 & 378.15 \\
\hline Cumulative 1947 NSIH Miles & 0 & 0 & 92.16 & 188.84 & 264.96 & 338.74 & 364.04 & 364.04 & 364.04 \\
\hline Cumulative Interstates Miles not in 1947 NSIH & 0 & 0 & 0 & 0 & 11.66 & 11.66 & 14.11 & 14.11 & 14.11 \\
\hline Percent of Counties Receiving Interstate Miles & 0 & 0 & 5.75 & 16.09 & 21.84 & 22.99 & 24.14 & 24.14 & 24.14 \\
\hline
\end{tabular}

Notes: The first interstate opened aftern 1950 but before 1954; therefore we do not report values for 1945 and 1950 . a: There are 10 urban counties in Georgia. We define an urban counties as those always in an MSA from 1950 through 2007 b: the acronym for the National System of Interstate Highwas is NSIH c: There are 62 transitory counites and we define transitory counties as those not in a MSA in 1950 but in an MSA in $2007 \mathrm{~d}$ : There are 87 rural counties in Georgia. We define a rural county as one that is never in an MSA from 1950 through 2007 
Table 4: OLS Regression Results for 1945 to 2007

Dependent variables: (1)-(7) Acreage of non-agricultural land; (8) change in acreage of non-agricultural land

\begin{tabular}{|c|c|c|c|c|c|c|c|c|}
\hline VARIABLES & $\begin{array}{c}(1) \\
\text { OLS } \\
\text { Base }\end{array}$ & $\begin{array}{c}(2) \\
\text { OLS } \\
\text { Year }\end{array}$ & $\begin{array}{c}\text { (3) } \\
\text { OLS } \\
\text { County }\end{array}$ & $\begin{array}{c}\text { (4) } \\
\text { OLS } \\
\text { Full }\end{array}$ & $\begin{array}{c}(5) \\
\text { OLS } \\
\text { NSIH } \\
\text { miles }\end{array}$ & $\begin{array}{c}\text { (6) } \\
\text { IV } \\
\text { NSIH } \\
\text { miles }\end{array}$ & $\begin{array}{c}(7) \\
\text { IV } \\
\text { NSIH } \\
\text { miles*fraction } \\
\text { complete } \\
\end{array}$ & $\begin{array}{c}(8) \\
\text { IV } \\
\text { Change in } \\
\text { NSIH miles }\end{array}$ \\
\hline Highway miles & $\begin{array}{c}1,611 * * * \\
(499.2)\end{array}$ & $\begin{array}{c}727.7 \\
(559.0)\end{array}$ & $\begin{array}{c}2,070 * * * \\
(229.7)\end{array}$ & $\begin{array}{c}468.1 * * \\
(221.5)\end{array}$ & & $\begin{array}{c}527.6 * * \\
(253.0)\end{array}$ & $\begin{array}{c}664.8 * * \\
(289.3)\end{array}$ & \\
\hline 1947 NSIH miles & & & & & $\begin{array}{c}558.1 * * \\
(280.5)\end{array}$ & & & \\
\hline Change in open 1947 NSIH miles & & & & & & & & $\begin{array}{c}503.7 * * * \\
(136.4)\end{array}$ \\
\hline County level population & $\begin{array}{l}0.0854 * \\
(0.0513)\end{array}$ & $\begin{array}{l}0.126 * * \\
(0.0564)\end{array}$ & $\begin{array}{c}0.0941 * * * \\
(0.0337)\end{array}$ & $\begin{array}{l}0.0454 * \\
(0.0236)\end{array}$ & $\begin{array}{c}0.0575 * * * \\
(0.0207)\end{array}$ & $\begin{array}{l}0.0409 * \\
(0.0247)\end{array}$ & $\begin{array}{c}0.0305 \\
(0.0278)\end{array}$ & \\
\hline Crop revenue & $\begin{array}{c}-2.511^{* * * *} \\
(0.709)\end{array}$ & $\begin{array}{c}-1.744 * * \\
(0.687)\end{array}$ & $\begin{array}{c}-5.831^{* * *} \\
(0.728)\end{array}$ & $\begin{array}{l}-0.978 * \\
(0.538)\end{array}$ & $\begin{array}{l}-0.962 * \\
(0.534)\end{array}$ & $\begin{array}{l}-0.988 * \\
(0.516)\end{array}$ & $\begin{array}{c}-1.009 * * \\
(0.515)\end{array}$ & \\
\hline Previous rainfall & $\begin{array}{c}-778.0 * * * \\
(290.4)\end{array}$ & $\begin{array}{l}-378.3 \\
(481.4)\end{array}$ & $\begin{array}{c}-238.6^{* * * *} \\
(91.49)\end{array}$ & $\begin{array}{c}334.6^{* * * *} \\
(102.9)\end{array}$ & $\begin{array}{c}328.3 * * * \\
(102.7)\end{array}$ & $\begin{array}{c}334.7 * * * \\
(98.55)\end{array}$ & $\begin{array}{c}334.9 * * * \\
(98.77)\end{array}$ & \\
\hline Change in county level population & & & & & & & & $\begin{array}{l}-0.0689 \\
(0.0660)\end{array}$ \\
\hline Change in previous rainfall & & & & & & & & $\begin{array}{c}120.3 * * \\
(47.06)\end{array}$ \\
\hline Change in crop revenue & & & & & & & & $\begin{array}{c}-1.127 * * * \\
(0.321)\end{array}$ \\
\hline Constant & $\begin{array}{c}160,013 * * * \\
(13,987) \\
\end{array}$ & $\begin{array}{c}102,656 * * * \\
(24,484) \\
\end{array}$ & $\begin{array}{c}290,541 * * * \\
(18,003) \\
\end{array}$ & $\begin{array}{c}93,849 * * * \\
(15,400) \\
\end{array}$ & $\begin{array}{c}93,704 * * * \\
(15,354) \\
\end{array}$ & $\begin{array}{c}94,406 * * * \\
(14,793) \\
\end{array}$ & $\begin{array}{c}95,690 * * * \\
(14,821) \\
\end{array}$ & $\begin{array}{c}5,925 * * * \\
(351.4) \\
\end{array}$ \\
\hline Year Dummies & No & Yes & No & Yes & Yes & Yes & Yes & No \\
\hline County Dummies & No & No & Yes & Yes & Yes & Yes & Yes & No \\
\hline Observations & 2,222 & 2,222 & 2,222 & 2,222 & 2,222 & 2,222 & 2,222 & 2,063 \\
\hline R-squared & 0.294 & 0.368 & 0.874 & 0.939 & 0.939 & 0.939 & 0.939 & \\
\hline Adjusted R-squared & 0.292 & 0.363 & 0.864 & 0.934 & 0.934 & 0.934 & 0.934 & \\
\hline
\end{tabular}

Robust standard errors in parentheses; $* * * \mathrm{p}<0.01, * * \mathrm{p}<0.05, * \mathrm{p}<0.1$; The acronym for the 1947 National System of Interstate Highways is $1947 \mathrm{NSIH}$; Column (5) contains open highway miles in the 1947 NSIH as a regressor instead of all, open interstate highway miles; Columns (6), (7), \& (8) contain the IV regression results when the instruments are: open interstate miles $1947 \mathrm{NSIH}$ plan miles, the interaction between $1947 \mathrm{NSIH}$ miles times the fraction of NSIH miles completed by a given year in the state, and the change in opened 1947 NSIH miles 
Table 5: First Stage Regression Results from IV Regressions

Dependent variable: (1) \& (2) Open Interstate Highway Miles; (3) Change in Open Interstate Highway Miles

\begin{tabular}{|c|c|c|c|}
\hline VARIABLES & $\begin{array}{c}(1) \\
\text { NSIH } \\
\text { Miles }^{\text {a }} \\
\end{array}$ & $\begin{array}{c}(2) \\
\text { NSIH Miles * Fraction Complete } \\
\end{array}$ & $\begin{array}{c}(3) \\
\text { Change in NSIH Miles }^{\mathrm{a}} \\
\end{array}$ \\
\hline Open NSIH Miles ${ }^{\mathrm{a}}$ & $\begin{array}{l}1.058 * * * \\
(0.0428)\end{array}$ & & \\
\hline NSIH Miles $*$ Fraction Complete ${ }^{a}$ & & $\begin{array}{c}1.069 * * * \\
(0.0462)\end{array}$ & \\
\hline Change in Open NSIH Miles ${ }^{a}$ & & & $\begin{array}{l}1.056 * * * \\
(0.0361)\end{array}$ \\
\hline County Level Population & $\begin{array}{c}3.16 \mathrm{e}- \\
05 * * * \\
(9.68 \mathrm{e}-06)\end{array}$ & $\begin{array}{c}2.72 \mathrm{e}-05 * * \\
(1.05 \mathrm{e}-05)\end{array}$ & \\
\hline Crop Revenue & $\begin{array}{c}4.90 \mathrm{e}-05 \\
(3.26 \mathrm{e}-05)\end{array}$ & $\begin{array}{l}6.65 \mathrm{e}-05^{*} \\
(3.81 \mathrm{e}-05)\end{array}$ & \\
\hline Previous Change Fall & $\begin{array}{l}-0.0120^{*} \\
(0.00622)\end{array}$ & $\begin{array}{c}-0.0253 * * \\
(0.0119)\end{array}$ & \\
\hline Change in County Level Population & & & $\begin{array}{c}1.83 \mathrm{e}-05 * * * \\
(6.15 \mathrm{e}-06)\end{array}$ \\
\hline Change in Previous Rainfall & & & $\begin{array}{c}-0.000422 \\
(0.00115)\end{array}$ \\
\hline Change in Crop Revenue & & & $\begin{array}{c}1.99 \mathrm{e}-06 \\
(7.47 \mathrm{e}-06)\end{array}$ \\
\hline Constant & $\begin{array}{l}-1.331 \\
(0.928)\end{array}$ & $\begin{array}{l}-1.086 \\
(1.160)\end{array}$ & $\begin{array}{c}0.0175 \\
(0.0208) \\
\end{array}$ \\
\hline Year Dummies & Yes & Yes & No \\
\hline County Dummies & Yes & Yes & No \\
\hline Observations & 2,222 & 2,222 & 2,063 \\
\hline R-squared & 0.968 & 0.935 & 0.867 \\
\hline F-Statistic ${ }^{\mathrm{b}}$ & 609.71 & 535.98 & 853.33 \\
\hline
\end{tabular}

Robust standard errors in parentheses; $* * * \mathrm{p}<0.01, * * \mathrm{p}<0.05, * \mathrm{p}<0.1$; a: the acronym for the 1947 National

System of Interstate Highways is NSIH; b: the reported F-statistics is adjusted for 159 county clusters; The instrument in column (1) is open highway miles in the $1947 \mathrm{NSIH}$, in column (2) is the $1947 \mathrm{NISH}$ miles multiplied by the fraction of $1947 \mathrm{NSIH}$ miles that are opened statewide and in column (3) is the change in open 1947 NSIH miles 
Table 6: OLS and IV Results using an Alternative Control Group 1947-2007

Dependent variables: (1)-(7) Acreage of non-agricultural land; (8) change in acreage of non-agricultural land

\begin{tabular}{|c|c|c|c|c|c|c|c|c|}
\hline VARIABLES & $\begin{array}{c}(1) \\
\text { OLS } \\
\text { Base }\end{array}$ & $\begin{array}{c}(2) \\
\text { OLS } \\
\text { Year }\end{array}$ & $\begin{array}{c}\text { (3) } \\
\text { OLS } \\
\text { County }\end{array}$ & $\begin{array}{l}\text { OLS } \\
\text { Full }\end{array}$ & $\begin{array}{c}\text { (5) } \\
\text { OLS } \\
\text { NSIH miles }\end{array}$ & $\begin{array}{c}\text { (6) } \\
\text { IV } \\
\text { NSIH miles }\end{array}$ & $\begin{array}{c}\text { (7) } \\
\text { IV } \\
\text { NSIH } \\
\text { miles*fraction } \\
\text { complete } \\
\end{array}$ & $\begin{array}{c}\text { (8) } \\
\text { IV } \\
\text { Change in NSIH } \\
\text { miles }\end{array}$ \\
\hline Highway miles & $\begin{array}{c}1,799 * * * \\
(494.7)\end{array}$ & $\begin{array}{c}793.2 \\
(573.7)\end{array}$ & $\begin{array}{c}2,002 * * * \\
(220.5)\end{array}$ & $\begin{array}{l}407.0 * \\
(213.3)\end{array}$ & & $\begin{array}{l}447.8 * \\
(244.4)\end{array}$ & $\begin{array}{l}576.8 * * \\
(282.3)\end{array}$ & \\
\hline 1947 NSIH miles & & & & & $\begin{array}{l}473.2 * \\
(272.1)\end{array}$ & & & \\
\hline Change in open 1947 NSIH miles & & & & & & & & $\begin{array}{c}489.7 * * * \\
(136.9)\end{array}$ \\
\hline County level population & $\begin{array}{c}0.0744 \\
(0.0509)\end{array}$ & $\begin{array}{l}0.120 * * \\
(0.0573)\end{array}$ & $\begin{array}{c}0.0868 * * * \\
(0.0307)\end{array}$ & $\begin{array}{c}0.0504 * * \\
(0.0228)\end{array}$ & $\begin{array}{c}0.0616 * * * \\
(0.0203)\end{array}$ & $\begin{array}{c}0.0474 * * \\
(0.0238)\end{array}$ & $\begin{array}{c}0.0382 \\
(0.0267)\end{array}$ & \\
\hline Crop revenue & $\begin{array}{c}-2.643 * * \\
(1.021)\end{array}$ & $\begin{array}{l}-1.484 \\
(0.976)\end{array}$ & $\begin{array}{c}-7.393 * * * \\
(1.238)\end{array}$ & $\begin{array}{c}-2.127 * * \\
(0.854)\end{array}$ & $\begin{array}{c}-2.085^{* *} \\
(0.840)\end{array}$ & $\begin{array}{c}-2.128 * * * \\
(0.814)\end{array}$ & $\begin{array}{c}-2.131 * * * \\
(0.811)\end{array}$ & \\
\hline Previous rainfall & $\begin{array}{c}-555.1 * * \\
(268.3)\end{array}$ & $\begin{array}{c}95.54 \\
(425.2)\end{array}$ & $\begin{array}{l}-109.0 \\
(102.9)\end{array}$ & $\begin{array}{c}477.7 * * * \\
(102.0)\end{array}$ & $\begin{array}{c}471.4 * * * \\
(101.5)\end{array}$ & $\begin{array}{c}477.9 * * * \\
(97.63)\end{array}$ & $\begin{array}{c}478.6^{* * *} \\
(98.20)\end{array}$ & \\
\hline Change in county level population & & & & & & & & $\begin{array}{l}-0.0789 \\
(0.0675)\end{array}$ \\
\hline Change in previous rainfall & & & & & & & & $\begin{array}{c}139.7 * * * \\
(52.94)\end{array}$ \\
\hline Change in crop revenue & & & & & & & & $\begin{array}{c}-1.285^{* *} \\
(0.512)\end{array}$ \\
\hline Constant & $\begin{array}{c}146,593 * * * \\
(14,706) \\
\end{array}$ & $\begin{array}{c}72,084 * * * \\
(22,955) \\
\end{array}$ & $\begin{array}{c}325,267 * * * \\
(30,384) \\
\end{array}$ & $\begin{array}{c}114,936 * * * \\
(24,186) \\
\end{array}$ & $\begin{array}{c}114,065^{* * *} * \\
(23,938)\end{array}$ & $\begin{array}{c}115,193 * * * \\
(23,134) \\
\end{array}$ & $\begin{array}{c}116,006 * * * \\
(23,158) \\
\end{array}$ & $\begin{array}{c}6,233 * * * \\
(409.0) \\
\end{array}$ \\
\hline Year Dummies & No & Yes & No & Yes & Yes & Yes & Yes & No \\
\hline County Dummies & No & No & Yes & Yes & Yes & Yes & Yes & No \\
\hline Observations & 1,748 & 1,748 & 1,748 & 1,748 & 1,748 & 1,748 & 1,748 & 1,623 \\
\hline R-squared & 0.269 & 0.357 & 0.863 & 0.937 & 0.937 & 0.937 & 0.937 & 0.018 \\
\hline Adjusted R-squared & 0.267 & 0.351 & 0.852 & 0.932 & 0.932 & 0.932 & 0.931 & \\
\hline
\end{tabular}

Robust standard errors in parentheses; *** p<0.01, ** $\mathrm{p}<0.05, * \mathrm{p}<0.1$; The acronym for the 1947 National System of Interstate Highways is 1947 NSIH; Column $(5)$ contains open highway miles in the $1947 \mathrm{NSIH}$ as a regressor instead of all, open interstate highway miles; Columns (6), (7), \& (8) contain the IV regression results when the instruments are: open interstate miles 1947 NSIH plan miles, the interaction between 1947 NSIH miles times the fraction of NSIH miles completed by a given year in the state, and the change in opened 1947 NSIH miles. Highway counties are those that contain an interstate highway. Buffer counties are those counties that are adjacent to a county that contains an interstate highway (see Figure 5). 
Table 7: Regression Results for 1945 to 2007 for Rural, Transitory, and Urban Counties

\begin{tabular}{ccccc} 
Dependent Variable: Acres of Non-Agricultural Land & & \\
\hline & $(1)$ & $(2)$ & $(3)$ & $(4)$ \\
Urban
\end{tabular}

Robust standard errors in parentheses

$$
* * * \mathrm{p}<0.01, * * \mathrm{p}<0.05, * \mathrm{p}<0.1
$$

a: There are 10 urban counties in Georgia. We define an urban counties as those always in an MSA from 1950 through 2007 b: the acronym for the National System of Interstate Highways is NSIH c: There are 62 transitory counties and we define transitory counties as those not in a MSA in 1950 but in an MSA in $2007 \mathrm{~d}$ : There are 87 rural

counties in Georgia. We define a rural county as one that is never in an MSA from 1950 through 2007 
Table 8: Results for Northern Arc and Outer Perimeter Simulations

\begin{tabular}{|c|c|c|c|c|c|c|c|c|c|c|}
\hline \multirow[b]{2}{*}{ County } & \multirow[b]{2}{*}{$\begin{array}{l}\text { Model } \\
\text { Prediction }\end{array}$} & \multicolumn{3}{|c|}{ Northern Arc } & \multicolumn{3}{|c|}{ Outer Perimeter Alternative A } & \multicolumn{3}{|c|}{ Outer Perimeter Alternative B } \\
\hline & & $\begin{array}{c}\text { Highway } \\
\text { Mileage }\end{array}$ & $\begin{array}{l}\text { Simulation } \\
\text { Prediction }\end{array}$ & $\begin{array}{l}\text { Percent } \\
\text { Change }\end{array}$ & Mileage & $\begin{array}{l}\text { Simulation } \\
\text { Prediction }\end{array}$ & $\begin{array}{l}\text { Percent } \\
\text { Change }\end{array}$ & Mileage & $\begin{array}{l}\text { Simulation } \\
\text { Prediction }\end{array}$ & $\begin{array}{l}\text { Percent } \\
\text { Change }\end{array}$ \\
\hline Cherokee & 241942 & 24.04 & 253195 & $4.65 \%$ & 24.04 & 253195 & $4.65 \%$ & 24.04 & 253195.3 & $4.65 \%$ \\
\hline Gwinnett & 257492 & 14.73 & 264387 & $2.68 \%$ & 27.15 & 270201 & $4.94 \%$ & 27.15 & 270201.2 & $4.94 \%$ \\
\hline Forsyth & 111929 & 11.36 & 117245 & $4.75 \%$ & 11.36 & 117245 & $4.75 \%$ & 11.36 & 117244.7 & $4.75 \%$ \\
\hline Bartow & 203407 & 5.55 & 206005 & $1.28 \%$ & 25.19 & 215197 & $5.80 \%$ & 25.19 & 215196.8 & $5.80 \%$ \\
\hline Carroll & 224688 & 0.00 & 224688 & $0.00 \%$ & 23.04 & 235472 & $4.80 \%$ & 25.23 & 236499.2 & $5.26 \%$ \\
\hline Henry & 160455 & 0.00 & 160455 & $0.00 \%$ & 19.47 & 169571 & $5.68 \%$ & 13.55 & 166795.5 & $3.95 \%$ \\
\hline Coweta & 209208 & 0.00 & 209208 & $0.00 \%$ & 17.94 & 217605 & $4.01 \%$ & 31.90 & 224138.5 & $7.14 \%$ \\
\hline Paulding & 180881 & 0.00 & 180881 & $0.00 \%$ & 11.04 & 186051 & $2.86 \%$ & 11.04 & 186050.6 & $2.86 \%$ \\
\hline Fayette & 107191 & 0.00 & 107191 & $0.00 \%$ & 10.82 & 112257 & $4.73 \%$ & 0.00 & 107191 & $0.00 \%$ \\
\hline Polk & 154227 & 0.00 & 154227 & $0.00 \%$ & 10.52 & 159152 & $3.19 \%$ & 10.52 & 159152.4 & $3.19 \%$ \\
\hline Rockdale & 84921 & 0.00 & 84921 & $0.00 \%$ & 10.11 & 89652 & $5.57 \%$ & 10.11 & 89651.84 & $5.57 \%$ \\
\hline Newton & 130425 & 0.00 & 130425 & $0.00 \%$ & 9.72 & 134977 & $3.49 \%$ & 9.72 & 134976.7 & $3.49 \%$ \\
\hline Spalding & 101340 & 0.00 & 101340 & $0.00 \%$ & 7.73 & 104956 & $3.57 \%$ & 23.61 & 112393.5 & $10.91 \%$ \\
\hline Fulton & 321903 & 0.00 & 321903 & $0.00 \%$ & 1.12 & 322429 & $0.16 \%$ & 0.00 & 321903 & $0.00 \%$ \\
\hline Douglas & 134072 & 0.00 & 134072 & $0.00 \%$ & 0.59 & 134350 & $0.21 \%$ & 0.00 & 134072 & $0.00 \%$ \\
\hline Butts & 95669 & 0.00 & 95669 & $0.00 \%$ & 0.00 & 95669 & $0.00 \%$ & 6.95 & 98921.69 & $3.40 \%$ \\
\hline Lamar & 86979 & 0.00 & 86979 & $0.00 \%$ & 0.00 & 86979 & $0.00 \%$ & 1.13 & 87506.14 & $0.61 \%$ \\
\hline Pike & 95370 & 0.00 & 95370 & $0.00 \%$ & 0.00 & 95370 & $0.00 \%$ & 1.40 & 96026.34 & $0.69 \%$ \\
\hline Total & 2902097 & 56 & 2928158 & $0.90 \%$ & 210 & 3000328 & $3.38 \%$ & 233 & 3011116 & $3.76 \%$ \\
\hline
\end{tabular}

Predictions are reported of acres of non-agricultural land. Mileage is reported in miles. Percent change represents the percent change in non-

agricultural land as a result of receiving the mileage of new highway. 
Table 9: Results for 14th Amendment Highway Simulation

\begin{tabular}{|c|c|c|c|c|c|}
\hline County & $\begin{array}{l}\text { 14th } \\
\text { Amendment } \\
\text { Highway } \\
\text { Miles } \\
\end{array}$ & $\begin{array}{l}\text { New 14th } \\
\text { Amendment } \\
\text { Highway } \\
\text { Miles }\end{array}$ & $\begin{array}{l}\text { Predicted } \\
\text { Acreage } \\
\text { without } \\
\text { Highway } \\
\end{array}$ & $\begin{array}{l}\text { Predicted } \\
\text { Acreage } \\
\text { with } \\
\text { Highway } \\
\end{array}$ & Percent Change \\
\hline Washington & 0.79 & 0.79 & 265,083 & 265,455 & $0.14 \%$ \\
\hline Jones & 1.22 & 1.22 & 221,265 & 221,834 & $0.26 \%$ \\
\hline Columbia $^{a}$ & 17.65 & 1.49 & 159,031 & 159,731 & $0.44 \%$ \\
\hline Harris & 3.55 & 3.55 & 246,431 & 248,091 & $0.67 \%$ \\
\hline Twiggs & 6.39 & 6.39 & 202,376 & 205,367 & $1.48 \%$ \\
\hline Baldwin & 8.14 & 8.14 & 128,003 & 131,812 & $2.98 \%$ \\
\hline $\mathrm{Bibb}^{\mathrm{b}}$ & 21.39 & 8.65 & 152,497 & 156,544 & $2.65 \%$ \\
\hline McDuffie & 13.34 & 13.34 & 138,524 & 144,770 & $4.51 \%$ \\
\hline Warren & 15.12 & 15.12 & 126,740 & 133,818 & $5.58 \%$ \\
\hline Muscogee & 16.13 & 16.13 & 151,090 & 158,642 & $5.00 \%$ \\
\hline Wilkinson & 17.26 & 17.26 & 240,799 & 248,881 & $3.36 \%$ \\
\hline Talbot & 18.22 & 18.22 & 199,403 & 207,931 & $4.28 \%$ \\
\hline Taylor & 18.38 & 18.38 & 161,012 & 169,615 & $5.34 \%$ \\
\hline Crawford & 19.68 & 19.68 & 160,943 & 170,154 & $5.72 \%$ \\
\hline Hancock & 21.17 & 21.17 & 237,714 & 247,622 & $4.17 \%$ \\
\hline Richmond $^{\mathrm{c}, \mathrm{d}}$ & 1.66 & 0.00 & 202,827 & 202,827 & $0.00 \%$ \\
\hline Total & 200.09 & 169.53 & $2,993,736$ & $3,073,094$ & $2.65 \%$ \\
\hline
\end{tabular}

Notes: Predicted quantities are in acres of non-agricultural land. a: 17.65 miles of the 14th Amendment highway run along I-20 b: 21.39 miles run along I-75 and I-16 c: 1.66 miles run along I-20 d: Richmond county contains no new interstate miles since they are all contains along $\mathrm{I}-20$ 
